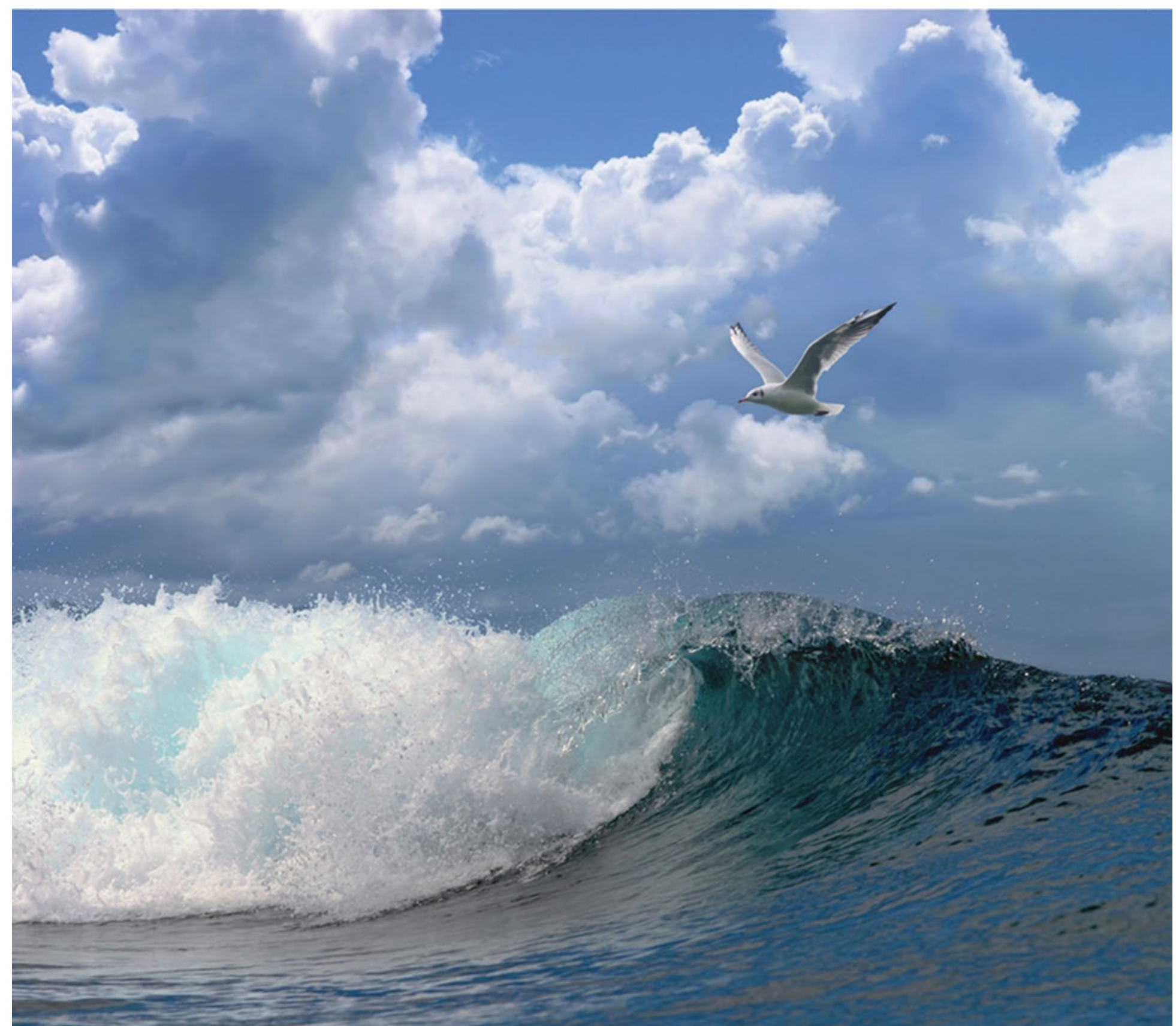

\title{
Ecologische effecten van MSC Zoe polystyreen-korrels onderzocht in experimentele marine ecosystemen
}

Auteur(s): Edwin Foekema, Martijn Keur, Liesbeth van der Vlies, Babeth van der Weide, Oliver Bittner 


\title{
Ecologische effecten van MSC Zoe polystyreen-korrels onderzocht in experimentele marine ecosystemen
}

\author{
Auteur(s): $\quad$ Edwin Foekema, Martijn Keur, Liesbeth van der Vlies, Babeth van der Weide, \\ Oliver Bittner
}

Wageningen Marine Research 
Keywords: MSC Zoe, containers, polystyreen korrels, mesocosms, microplastics

Opdrachtgever: Rijkswaterstaat Water, Verkeer en Leefomgeving

Griffioenlaan 2

3526 LA Utrecht

Dit rapport is gratis te downloaden van https://doi.org/10.18174/543191

Wageningen Marine Research verstrekt geen gedrukte exemplaren van rapporten.

Wageningen Marine Research is ISO 9001:2015 gecertificeerd.

\section{(c) Wageningen Marine Research}

Wageningen Marine Research, instituut binnen de rechtspersoon Stichting

Wageningen Research, hierbij

vertegenwoordigd door

Dr. ir. J.T. Dijkman, Managing director

KvK nr. 09098104,

WMR BTW nr. NL 8113.83.696.B16.

Code BIC/SWIFT address: RABONL2U

IBAN code: NL 73 RABO 0373599285
Wageningen Marine Research aanvaardt geen aansprakelijkheid voor gevolgschade, noch voor schade welke voortvloeit uit toepassingen van de resultaten van werkzaamheden of andere gegevens verkregen van Wageningen Marine Research. Opdrachtgever vrijwaart Wageningen Marine Research van aanspraken van derden in verband met deze toepassing.

Alle rechten voorbehouden. Niets uit deze uitgave mag weergegeven en/of gepubliceerd worden, gefotokopieerd of op enige andere manier gebruikt worden zonder schriftelijke toestemming van de uitgever of auteur. 


\section{Inhoud}

$\begin{array}{lr}\text { Samenvatting } & 4\end{array}$

$1 \quad$ Inleiding $\quad 5$

1.1 Mesocosm onderzoek $\quad 5$

1.2 Doel van het onderzoek $\quad 5$

2 Materiaal en methoden $\quad 6$

2.1 Mesocosm inrichting $\quad 6$

2.2 Behandelingen en dosering 6

$\begin{array}{lll}2.2 .1 & \text { PS-korrels } & 6\end{array}$

$\begin{array}{lll}\text { 2.2.2 Doseringsreeks en dosering } & 7\end{array}$

$\begin{array}{llr}2.3 & \text { Bemonsteringen en analyses } & 8\end{array}$

2.3.1 Tussentijdse bemonsteringen en analyses 9

2.3.2 Eindbemonstering $\quad 9$

2.3.3 Bepalen van PS-korrels in monsters 10

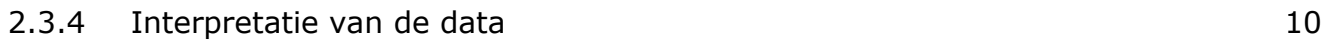

$\begin{array}{llr}3 & \text { Resultaten } & 11\end{array}$

3.1 Water karakteristieken $\quad 11$

3.2 Verdeling PS-korrels in sediment en water $\quad 12$

$\begin{array}{ll}3.3 & \text { Ontwikkeling biota } \\ & 3.3 .13\end{array}$

$\begin{array}{ll}\text { 3.3.1 Planktongemeenschap } & 13\end{array}$

$\begin{array}{lll}3.3 .2 & \text { Perifyton } & 14\end{array}$

$\begin{array}{ll}3.3 .3 & \text { Benthos gemeenschap }\end{array}$

$\begin{array}{ll}\text { 3.3.4 Geïntroduceerde soorten } & 18\end{array}$

$\begin{array}{lll}3.4 & \text { Interacties biota met PS-korrels } & 23\end{array}$

$\begin{array}{lll}3.4 .1 & \text { Schelpdieren } & 23\end{array}$

$\begin{array}{lll}3.4 .2 \text { Wormen } & 24\end{array}$

$\begin{array}{lll}3.4 .3 & \text { Vissen } & 24\end{array}$

4 Discussie en conclusies $\quad 26$

4.1 Vertaalbaarheid naar veldsituatie $\quad 26$

4.2 Verspreiding van de PS-korrels in het milieu 26

$\begin{array}{lll}4.3 & \text { Ecologische effecten van de PS-korrels } & 26\end{array}$

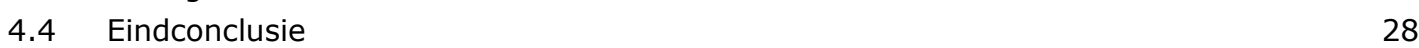

$\begin{array}{llr}5 & \text { Kwaliteitsborging } & 29\end{array}$

$\begin{array}{lr}\text { Literatuur } & \mathbf{3 0}\end{array}$

$\begin{array}{lr}\text { Verantwoording } & 31\end{array}$ 


\section{Samenvatting}

Begin januari 2019 verloor containerschip MSC Zoe ten noorden van de Waddeneilanden een deel van haar lading. Naast ander materiaal, kwamen hierbij microplastics in zee terecht in de vorm van ca. 5 $\mathrm{mm}$ grote high density polyethylene (HDPE)-pellets en ca. $0.5 \mathrm{~mm}$ grote polystyreen (PS)-korrels. In opdracht van RWS-NN is door Wageningen Marine Research onderzoek in outdoor mesocosms uitgevoerd naar de ecologische effecten van de PS-korrels. De mesocosms werden ingericht met in de Waddenzee voorkomende ongewervelden en met juveniele platvis (tong). Na de toevoeging van een concentratiereeks van $0.1,0.8,8.0$ en 80 gram PS-korrels per $\mathrm{m}^{2}$ werd de ontwikkeling van de organismen en ecosysteem in de mesocosms gedurende 56 dagen gevolgd.

Er ontstonden verschillende effecten na de dosering van de PS-korrels.

Statistisch significant waren:

- $\quad$ een eenmalig lagere dichtheid copepoden, de dominante zoöplankton groep, in de $80 \mathrm{~g} / \mathrm{m}^{2}$ mesocosms;

- $\quad$ lagere dichtheden zeepokken vanaf $0.8 \mathrm{~g} / \mathrm{m}^{2}$;

- $\quad$ hogere dichtheid van schelpdieren en wormen in de $0.8 \mathrm{~g} / \mathrm{m}^{2}$ mesocosms voor een deel van de soorten gevolgd door een afname bij hogere concentraties;

- $\quad$ een hogere dichtheid van de wormen Spionidae sp. in de $80 \mathrm{~g} / \mathrm{m}^{2}$ mesocosms;

- $\quad$ een iets hoger vleesgewicht van mosselen in de $80 \mathrm{~g} / \mathrm{m}^{2}$ mesocosms;

- $\quad$ een iets lagere conditie factor van de tong uit de $0.8 \mathrm{~g} / \mathrm{m}^{2}$ en de $80 \mathrm{~g} / \mathrm{m}^{2}$ mesocosms.

De hogere dichtheden van schelpdieren en wormen in de $0.8 \mathrm{~g} / \mathrm{m}^{2}$ mesocosms is mogelijk het gevolg van verminderde begrazingsdruk op hun larven door zeepokken. De biodiversiteit in de mesocosms werd hierdoor niet beïnvloed.

In de laagste testconcentratie $\left(0.1 \mathrm{~g} / \mathrm{m}^{2}\right)$ werden in de mesocosms geen statistisch significante afwijkingen van de blanco's gevonden. Dit kwam overeen met 326 PS-korrels per $\mathrm{m}^{2}$, en het scenario dat alle door MSC Zoe verloren PS-korrels zich homogeen verspreid hebben over 10\% (ca. 15.000 ha) van het oppervlak van de Nederlandse Waddenzee. Hogere onderzochte concentraties, vanaf 3.260 korrels per $\mathrm{m}^{2}\left(0.8 \mathrm{~g} / \mathrm{m}^{2}\right)$, veroorzaakten wel significante effecten op zeepokken, bodemfauna en juveniele platvis (tong). Tot en met de hoogst geteste concentratie van meer dan 300.000 korrels per $\mathrm{m}^{2}$ bleef de omvang van de effecten beperkt. Pelagische plankton-etende vis is in deze studie niet onderzocht. Het risico voor vissen als geheel is hierdoor mogelijk onderschat, omdat plankton-etende vis wellicht minder goed kunnen omgaan met onverteerbare ingeslikte (plastic) deeltjes dan bodemvissen die gewend zijn ook schelpen en zand in te slikken. 


\section{Inleiding}

Begin januari 2019 verloor containerschip MSC Zoe ten noorden van de Waddeneilanden een deel van haar lading. Naast ander materiaal, kwamen hierbij microplastics in zee terecht in de vorm van ca. 5 $\mathrm{mm}$ grote high density polyethylene (HDPE)-pellets en ca. $0.5 \mathrm{~mm}$ grote polystyreen (PS)-korrels. In 2019 zijn door NIOZ en WMR veelal in het kader van ander onderzoek monsters verzameld van water, sediment, vissen, vogels en zeezoogdieren die in 2020, in opdracht van Rijkswaterstaat, zijn onderzocht op de aanwezigheid van deze microplastics.

Naast dit onderzoek van veldmonsters is door WMR ook onderzoek uitgevoerd naar de ecologische effecten van de PS-korrels. Hiervoor werden outdoor mesocosms ingezet. Dit rapport beschrijft de opzet en de resultaten van dat mesocosm onderzoek.

\subsection{Mesocosm onderzoek}

Mesocosms laten zich het eenvoudigst omschrijven als proefvijvers, in dit geval gevuld met zoutwater, sediment en een mariene levensgemeenschap. Elke mesocosm vormt een stand-alone ecosysteempje waarin de basis van de marien voedselketen (primaire producenten: fytoplankton, perifyton, macroalgen, en primaire en secundaire consumenten: zoöplankton, schelpdieren, kreeftachtigen, wormen en eventueel kleine vis) vertegenwoordigd is. In een goed uitgevoerde mesocosmstudie worden niet alleen de directe effecten van een verstoring zichtbaar maar ook indirecte effecten als gevolg van interacties tussen soorten onderling en met hun omgeving. De omvang en de stabiliteit maken het mogelijk de impact gedurende langere tijd te volgen, onder condities die de omstandigheden in het veld benaderen. Mesocosms worden vaak gezien als een brug tussen laboratoriumexperimenten en veldwaarnemingen doordat zij de complexiteit van de veldsituatie benaderen, met de mogelijkheid tot controle en replicatie zoals in laboratoriumexperimenten.

\subsection{Doel van het onderzoek}

Het primaire doel van het onderzoek was inzicht te krijgen in de potentiele effecten van de door de MSC-Zoe verloren PS-korrels op de levensgemeenschap van de Waddenzee. Het onderzoek werd uitgevoerd met een concentratiereeks zodat de resultaten aan de veldsituatie kunnen worden gerelateerd op basis van de verdeling van de PS-korrels in de Waddenzee zoals bepaald aan de hand van veldmetingen en/of ingeschat op basis van verspreidingsmodellen. 


\section{Materiaal en methoden}

\subsection{Mesocosm inrichting}

De mesocosms werden ingericht in ronde polyester bakken voorzien van een inerte coating, met en diameter van 2 meter, een diepte van 2 meter en een totaal volume van ruim $5 \mathrm{~m}^{3}$. In totaal zijn voor dit project 30 mesocosms ingezet. Deze bevinden zich in de buitenlucht op de WMR testfaciliteit in Den Helder en zijn ten bate van temperatuurbuffering en werkgemak tot halve diepte ingegraven.

Op 8 april 2020 werden de 30 mesocosms, na te zijn voorzien van een ca. $15 \mathrm{~cm}$ dikke laag fijn zand, simultaan gevuld met zout water dat een week eerder met een schip in het Marsdiep was verzameld. De gevulde mesocosms werden vervolgens in twee groepen van 15 verdeeld, en het water binnen elke groep werd tussen de mesocosms gecirculeerd. De waterkolom van elke mesocosm werd in beweging gehouden door het op halve waterdiepte via een bruissteen te beluchten. Om de mesocosms te beschermen tegen regenval en vogelpoep werden ze voorzien van transparante polycarbonaat deksels.

Eén van de twee groepen van 15 mesocosms werd in een later stadium van jonge vis (tong) voorzien, de andere 15 mesocosms bleven zonder vis. Beide groepen kregen dezelfde concentratiereeks PSkorrels toegediend. Feitelijk is de behandeling dus gerepliceerd met en zonder vis. De reden om voor de vis speciale mesocosms in te richten ligt in de wetenschap dat de aanwezigheid van vis een substantiële invloed heeft op de ontwikkeling van het ecosysteem in de mesocosms. Het wordt daardoor lastiger om effecten van de behandeling -in dit geval de aanwezigheid van PS-korrels- vast te stellen met name op soorten die door de vissen als prooi worden benut. Door de gevolgde proefopzet was het mogelijk om effecten op evertebraten zonder verstoring van vis te onderzoeken, en tegelijkertijd in de andere serie de effecten op de vissen in beeld te brengen. Bovendien is het met deze opzet mogelijk om vast te stellen of eventueel waargenomen effecten op de vissen het gevolg zijn van de blootstelling aan het plastic (direct effect) of veroorzaakt wordt door een effect van het plastic op hun prooidieren (indirect effect). Alle handelingen aan de vissen zijn uitgevoerd conform de door de Centrale Commissie Dierproeven verleende vergunning voor de Wet op de Dierproeven, nummer: 2020D-0005.

$\mathrm{Na}$ een week circuleren werd aan elke mesocosm een gelijke hoeveelheid (ca. $4 \mathrm{~L}$ ) gezeefd en gehomogeniseerd slib uit de Waddenzee toegevoegd als ent voor meiofauna, en extra bron van nutriënten. Gedurende de volgende twee weken werden grotere organismen in de mesocosms gebracht. Per mesocosm ging het om 20 kokkels, 20 wadpieren en 50 alikruiken. In de 15 mesocosms waarin geen vis zou worden uitgezet werden tevens 20 mosselen in mandjes in de waterkolom gehangen. In de mesocosms waar de vis in werd uitgezet zijn geen mosselen geplaatst zodat er meer fytoplankton beschikbaar bleef voor de prooidieren van de vissen (zoöplankton en benthos). De acclimatisatieperiode waarin de watercirculatie tussen de mesocosms in stand werd gehouden werd na 5 weken, op 12 mei 2020 beëindigd door de watercirculatie te stoppen. Vanaf dat moment waren de mesocosms van elkaar geïsoleerd. De volgende dag (13 mei 2020; Dag 0) werd de dosering uitgevoerd, waarna de ontwikkeling in de mesocosms werd gevolgd totdat op 8 juli (mesocosm zonder vis) en 15 juli 2020 (mesocosm met vis) de eindbemonsteringen werd uitgevoerd en de proef werd beëindigd.

Details over bemonsteringen en analyses zijn te vinden in paragraaf 2.3 .

\subsection{Behandelingen en dosering}

\subsubsection{PS-korrels}

De door MSC Zoe verloren PS-korrels vormen de industriële basis voor piepschuim. Het zijn transparante ronde balletjes met een gemiddelde diameter van $0.7 \mathrm{~mm}$, waarin het gas pentaan in 
niet zichtbare kleine belletjes is ingegoten. Bij de productie van piepschuim wordt het basismateriaal verwarmt tot $\mathrm{ca} .100^{\circ} \mathrm{C}$ waardoor het polystyreen zacht wordt terwijl het pentaan uitzet en het transparante korreltje zich 'ontpopt' tot een wit balletje piepschuim (Expanded Polystyreen, EPS) dat vele malen groter is (tot ca. $3 \mathrm{~mm}$ ) dan het basismateriaal. In geëxpandeerde vorm heeft het materiaal een zeer groot drijfvermogen, in vergelijking met niet geëxpandeerd polystyreen waarvan het soortelijk gewicht iets hoger is dan water.

Er was slechts een beperkte hoeveelheid PS-korrels beschikbaar die werkelijk uit de lading van MSCZoe afkomstig waren waardoor het niet mogelijk was de mesocosm proef met het originele materiaal uit te voeren. Als alternatief werden soortgelijke industriële PS-korrels verkregen via CARAT GmbH in Duitsland. Deze korrels, product code V2020-0065, waren met een diameter tussen 0.7 en $0.9 \mathrm{~mm}$ een fractie groter, maar verder qua samenstelling, vorm en uiterlijk gelijk aan de originele Zoe korrels.

Chemische GC-MS analyse in het laboratorium van Wageningen Marine Research na 3 daagse extractie van de 1 gram korrels in $10 \mathrm{ml}$ hexaan, toonde aan dat zowel de originele Zoe korrels als het vervangende materiaal van CARAT geen vlamvertragers of weekmakers bevatten. De enige stof die in de originele Zoe korrels kon worden aangetoond was acetophenone (CASnr. 98-86-2). Dit is een 'photopolymerization initiator' die wordt toegepast bij de productie van polymeren (https://www.tcichemicals.com/assets/brochure-pdfs/Brochure F2037 E.pdf, bezocht op 9 dec 2020). Acetophenone was in duidelijk hogere concentraties aanwezig in de CARAT korrels, samen met enkele andere niet te identificeren stoffen in veel lagere concentraties (Figuur 1). Acetophenone wordt ook toegepast in de farmaceutische en voedingsindustrie vanwege het amandel/fruit aroma. De stof komt ook van nature voor in bijvoorbeeld appels, abrikozen, banaan en rundvlees, en staat niet als giftig bekend (https://www.chemicalbook.com/CASEN 98-86-2.htm, bezocht op 18 nov 2020).

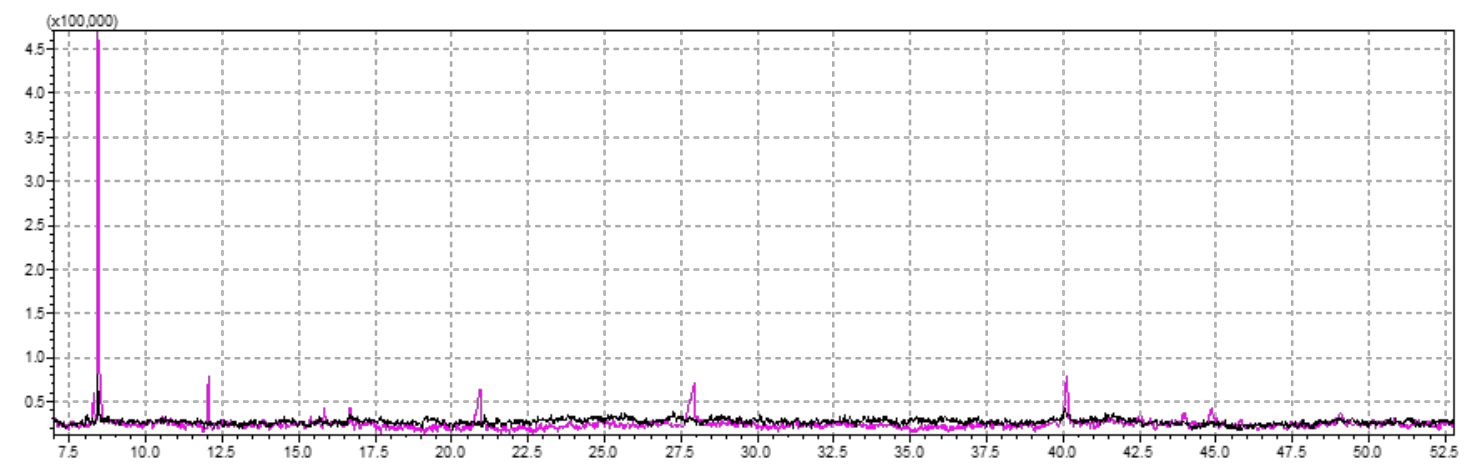

Figuur 1. GC-MS chromatogrammen van hexaan extracten van de originele Zoe PS-korrels (zwart) en de PSkorrels verkregen via CARAT GmbH die in de mesocosm studie zijn gebruikt (paars). De hoge paarse piek rond 8.4 wordt veroorzaakt door Acetophenone (CASnr. 98-86-2).

\subsubsection{Doseringsreeks en dosering}

Elke groep van 15 mesocosms bestond uit 3 onbehandelde blanco's en 4 testconcentraties in drievoud. De behandelingen werden verdeeld over de beschikbare mesocosms volgens een 'random block design'.

De basis voor de doseringsreeks (Tabel 1 ) is het scenario dat alle door de MSC Zoe verloren PSkorrels in de Nederlandse Waddenzee zijn beland en zich daar homogeen hebben verspreid over ten oosten van Schiermonnikoog. Dit betekent dat de ca. $11.000 \mathrm{~kg}$ korrels homogeen verspreid zijn over ca. $10 \%$ van het oppervlak van de Nederlandse Waddenzee, waarin dan 0,1 gram korrels per $\mathrm{m}^{2}$ aanwezig zijn. Dit vormde de laagste dosering in de mesocosm proef waarvoor 0,24 gram PS-korrels per mesocosm werd gedoseerd. In de drie volgende doseringen werden de hoeveelheden per mesocosm telkens met een factor 10 verhoogd, simulerend dat de totale hoeveelheid verloren PSkorrels zich geconcentreerd hebben over respectievelijk 1, 0,1 en 0,01\% van het oppervlak van de 
Nederlandse Waddenzee. In de hoogst gedoseerde mesocosms werd 240 gram PS-korrels toegevoegd wat leidde tot een belasting van 80 gram PS-korrels per $\mathrm{m}^{2}$.

Tabel 1. Gedoseerde hoeveelheid PS-korrels in grammen, geschat aantal per $\mathrm{m}^{2}$, en het oppervlak van de Waddenzee waar deze dosis zou kunnen zijn ontstaan. Dit is gebaseerd op de oppervlakte van de Waddenzee en de geschatte hoeveelheid van $11.250 \mathrm{~kg}$ PS-korrels die door MSC Zoe zou zijn verloren. De in de tabel aangegeven 'Dosis' wordt verder als aanduiding van de behandelingen gehanteerd. Elke behandeling werd in drievoud getest in mesocosms met en zonder vis.

\begin{tabular}{|l|l|l|}
\hline Dosis & $\mathbf{n} / \mathbf{m}^{\mathbf{2}}$ & Percentage oppervlak van Waddenzee (scenario) \\
\hline $0 \mathrm{~g} / \mathrm{m}^{2}$ & 0 & Blanco (geen PS-korrels in Waddenzee) \\
\hline $0,1 \mathrm{~g} / \mathrm{m}^{2}$ & 326 & $10 \%$ (alles ten oosten van Schiermonnikoog) \\
\hline $0,8 \mathrm{~g} / \mathrm{m}^{2}$ & 3.259 & $1 \%$ (geconcentreerd) \\
\hline $8 \mathrm{~g} / \mathrm{m}^{2}$ & 32.590 & $0,1 \%$ (sterk geconcentreerd) \\
\hline $80 \mathrm{~g} / \mathrm{m}^{2}$ & 325.900 & $0,01 \%$ (zeer sterk geconcentreerd) \\
\hline
\end{tabular}

De dosering werd uitgevoerd op 13 mei 2020 (Dag 0) door de afgewogen hoeveelheden PS-korrels gespreid over het wateroppervlak van de mesocosms uit te strooien.

\subsection{Bemonsteringen en analyses}

Een overzicht van de uitgevoerde analyses en bemonsteringen is gegeven in Tabel 2. In de volgende paragrafen worden de handelingen toegelicht.

Tabel 2. Fasering van de studie en bemonsteringsschema. Afkortingen: Water = temperatuur, saliniteit, $p H$, zuurstofgehalte en chlorofyl-A in alle 30 mesocosms; Zoopl=zoöplankton bemonstering in 15 mesocosm zonder vis; $N / P=$ nutriënten analyse in 15 mesocosm zonder vis; Perif = biomassa benthische algen bemonstering in 15 mesocosm zonder vis; Eind = eindbemonstering.

\begin{tabular}{|c|c|c|c|c|c|c|}
\hline 2020 & Dagnr. & Actie & \multicolumn{4}{|c|}{ Analyses } \\
\hline 9 April & -34 & water circulatie gestart & & & & \\
\hline 15 April & -28 & & Water & & & \\
\hline 17 April & -26 & Introductie slib, kokkels, mossels & & & & \\
\hline 22 April & -21 & Introductie wadpieren & Water & & & \\
\hline 29 April & -14 & & Water & & & \\
\hline 6 Mei & -7 & & Water & & & \\
\hline 11 Mei & -2 & Introductie alikruiken & & & & \\
\hline 12 Mei & -1 & Stop water circulatie & & & & \\
\hline 13 Mei & $\mathbf{0}$ & dosering & Water & zoopl & $\mathrm{N} / \mathrm{P}$ & \\
\hline 20 Mei & 7 & & Water & zoopl & $\mathrm{N} / \mathrm{P}$ & \\
\hline 27 Mei & 14 & & Water & zoopl & $\mathrm{N} / \mathrm{P}$ & \\
\hline 3 Juni & 21 & & Water & zoopl & $\mathrm{N} / \mathrm{P}$ & \\
\hline 4 Juni & 22 & Introductie vis in 'vis-mesocosms' & & & & \\
\hline 10 Juni & 28 & & Water & zoopl & $\mathrm{N} / \mathrm{P}$ & Perif \\
\hline 17 Juni & 35 & & Water & zoopl & $\mathrm{N} / \mathrm{P}$ & \\
\hline 24 Juni & 42 & & Water & zoopl & $\mathrm{N} / \mathrm{P}$ & Perif \\
\hline 1 Juli & 49 & & Water & zoopl & $\mathrm{N} / \mathrm{P}$ & \\
\hline 8 Juli & 56 & Eind zonder vis & Water & zoopl & $\mathrm{N} / \mathrm{P}$ & Perif \\
\hline 15 juli & 63 & Eind 'vis-mesocosms' & Water & zoopl & $\mathrm{N} / \mathrm{P}$ & \\
\hline
\end{tabular}




\subsubsection{Tussentijdse bemonsteringen en analyses}

Wekelijks zijn temperatuur, saliniteit, $\mathrm{pH}$, zuurstofgehalte en troebelheid van het water in de mesocosms bepaald op halve waterdiepte met behulp van electrodes (Mettler Toledo voor pH, HachLange HQ40D voor zuurstof, Hach-Lange HQ30D voor saliniteit en temperatuur).

De ontwikkeling van de algenbiomassa in de waterkolom is wekelijks bepaald aan de hand van het chlorofyl-a gehalte in watermonsters die op halve waterdiepte in de mesocosm werden verzameld. Het chlorofyl-a gehalte werd direct in het monster bepaald met behulp van een BBE Moldaenke algae analyser. Deze analyzer geeft tevens een indicatie van de bijdrage van de belangrijkste fytoplanktongroepen (diatomeeën, groenalgen en cyanobacteriën) aan het totale chlorofyl-a gehalte. Omdat geen effecten van de behandelingen op de fytoplanktongemeenschap werden verwacht is de tijdrovende analyse tot op soortniveau niet uitgevoerd. Monsters zijn wel opgeslagen voor eventuele nadere analyse op een later tijdstip.

Het hierboven beschreven analysepakket vormde de basis die wekelijks voor alle 30 mesocosms werd uitgevoerd. De hieronder beschreven meer tijdrovende analyses van zoöplankton en benthische algen zijn alleen uitgevoerd in de mesocosms waarin geen vis werd uitgezet.

De zoöplanktongemeenschap werd wekelijks bemonsterd door per kwadrant, dus op 4 posities, in de mesocosm een monster te nemen met een steekbuis, waardoor de gehele waterkolom wordt bemonsterd. Het zooplankton uit deze 4 monsters met een gezamenlijk volume van ca. $10 \mathrm{~L}$ werd verzameld in een $55 \mu \mathrm{m}$-planktonnet en geconserveerd in $4 \%$ formaldehyde, om later te worden geteld, waarbij slechts taxonomische hoofdgroepen werden onderscheiden. Monsters zijn opgeslagen voor eventuele nadere analyse op een later tijdstip.

Om de ontwikkeling van benthische algen (periphyton) te kunnen volgen werd op Dag 0 en Dag 28 in elke mesocosm een houder met daarin 4 schone glasplaatjes (Ixb) geplaatst. De houders werden op ca. $10 \mathrm{~cm}$ onder het wateroppervlak gehangen met de glasplaatjes gericht op het zuiden zodat zoveel mogelijk zonlicht opgevangen zou worden. Na 4 weken blootstelling, dus op dag 28 en dag 56, werd met microtiter plate reader BioteK $F L x 800$ de hoeveelheid chlorofyl op de glasplaatjes fluorometrisch bepaald als een maat voor de biomassa aan benthische algen die zich gedurende de blootstellingsperiode op de glasplaatjes heeft ontwikkeld.

\subsubsection{Eindbemonstering}

Tijdens de eindbemonstering werd de gehele mesocosm bemonsterd. Hierbij werd eerst de mesocosm leeggepompt over een $1 \mathrm{~mm}$ zeef, waarbij op de zeef achterblijvende organismen werden verzameld. Vervolgens werd uit elk kwadrant van de mesocosm, dus op 4 plaatsten, sediment cores $(40 \mathrm{~mm}$ diameter) verzameld op de bodem van het sediment, waarbij plekken met door wadpieren geproduceerde 'pierenhopen' werden vermeden. Deze cores werden verdeeld in drie diepte fracties: de bovenste $1 \mathrm{~cm}, 1$ tot $5 \mathrm{~cm}$, en $5 \mathrm{~cm}$ tot de bodem. Deze fracties werden samengevoegd per mesocosm en bewaard in de koelkast voor het vaststellen van het aantal PS-korrels op een later tijdstip.

Verse pierenhopen werden verzameld met een spatel en ook per mesocosm samengevoegd en koel bewaard voor latere analyse van het aantal PS-korrels.

$\mathrm{Na}$ het verzamelen van de sedimentmonsters werd al het sediment uit de mesocosm verzameld en over een $1 \mathrm{~mm}$ zeef gespoeld, waarbij alle op de zeef achterblijvende organismen werden verzameld. De geïntroduceerde mosselen, kokkels, alikruiken, wadpieren en vissen werden apart verzameld. Het resterende materiaal werd geconserveerd in $4 \%$ formaline om later in het laboratorium te worden gedetermineerd en geteld om de benthos gemeenschap te karakteriseren.

Van de geïntroduceerde mosselen en kokkels werd van elk levend aangetroffen individu de schelplengte en het vleesgewicht bepaald. Om praktische redenen werd van de alikruiken, naast schelplengte, niet het vleesgewicht bepaald maar het totaalgewicht van schelp en vlees gepaald. Van wadpieren is lichaamslengte niet accuraat te bepalen en werd alleen het individueel gewicht bepaald. Omdat de pieren grote hoeveelheden sediment bevatten werden deze dieren gewogen nadat zij gedurende de nacht in zeewater zonder sediment de darm hadden geleegd. Dit uitgepoepte 
sediment werd verzameld en onderzocht op de aanwezigheid van PS-korrels. Tenslotte werd geteld hoeveel zeepokken en andere organismen die als larven met het water in de mesocosms moeten zijn gebracht zich op de wanden van de mesocosms hadden ontwikkeld.

De eindbemonstering werd in alle 30 mesocosms op dezelfde wijze uitgevoerd. De taxonomische analyse van de benthosgemeenschap is alleen uitgevoerd voor de mesocosms waarin geen vis is uitgezet. Het materiaal uit de mesocosms met vis is wel verzameld en geconserveerd voor eventuele analyse op een later tijdstip.

Bij de bemonstering van de 15 mesocosms met vis werden vissen die op de zeef achterbleven direct overgebracht naar een emmer met een overdosering van het narcotiserende middel Aqui-S in zeewater, waarin zij snel verdoofd raakten en vervolgens stierven, waarna individueel gewicht en lichaamslengte werd vastgesteld. Alle geïntroduceerde soorten werden ingevroren bewaard om op een later tijdstip onderzocht te worden op de aanwezigheid van PS-korrels.

\subsubsection{Bepalen van PS-korrels in monsters}

De eigenschap van de PS-korrels om bij verhitting te expanderen tot opvallende drijvende witte balletjes piepschuim maakte het eenvoudig om de deeltjes op te sporen in de verzamelde sediment monsters, de uitgepoepte wadpieren(hoopjes), en de door mosselen geproduceerde pseudofeces. Het monster werd gewogen en vervolgens in een bekerglas met gedemineraliseerd water in een magnetronoven aan de kook gebracht. Na ca. 1 minuut goed doorkoken, werd het sediment doorgeroerd waarna de piepschuim balletjes aan het wateroppervlak geteld konden worden.

Voor het onderzoek in biota werd deze kookmethode niet toegepast, omdat dit de integriteit van het weefsel te veel zou aantasten waardoor eventuele aanwijzingen van de impact van het opgenomen deeltje verloren zouden kunnen gaan.

Mosselen, kokkels, en vissen werden onder een stereomicroscoop onderzocht op de aanwezigheid van PS-korrels in het maag-darm kanaal. Hierbij werd steeds begonnen met de dieren uit de hoogst gedoseerde mesocosms. Doordat bij mosselen en kokkels uit de hoogste en op een na hoogste dosering geen PS-korrels werden aangetroffen zijn deze dieren uit lagere doseringen niet verder onderzocht.

\subsubsection{Interpretatie van de data}

\section{Conditie-index}

Voor de schelpdieren en de vissen zijn de individuele lengte en gewichtsmetingen gebruikt om de conditie-index $\mathrm{K}$ te bepalen volgens de Fulton formule: $\mathrm{K}=100 \times \mathrm{W} / \mathrm{L}^{\mathrm{b}}$.

De soortspecifieke waarde voor ' $b$ ' is bepaald door van alle drie blanco mesocosms de meetwaarden van de soort samen te voegen en de relatie tussen lengte ( $L$ in $\mathrm{mm}$ ) en gewicht ( $W$ in gram) te fitten met de optie 'least squares fit' in GraphPad Prism V8.2.1, volgens de formule $W=a * L^{b}$. De waarde voor ' $b$ ' die hierbij werd gevonden werd in de Fulton formule ingevuld, die vervolgens gebruikt werd om de waarde ' $K$ ' te bepalen voor elke mesocosm, alsmede voor het uitgangsmateriaal. Deze waarde ' $K$ ' wordt in dit rapport aangeduid als de 'conditie factor' en is een relatieve waarde: hoe hoger de conditie factor, hoe hoger het lichaamsgewicht bij dezelfde lengte.

\section{Statistische significantie}

De resultaten zijn statistisch getoetst met behulp van het softwarepakket GraphPad PRISM v8. Met behulp van de daarin opgenomen Shapiro-Wilk test werd geverifieerd of de data set van de drie replica's voldeden aan een normale verdeling. Vervolgens werd de statistische significantie van verschillen tussen behandelingen en blanco's, en in enkele gevallen tussen behandelingen onderling, getoetst met de in hetzelfde software pakket opgenomen 'Unpaired, two-tailed T-test'. Verschillen zijn statistisch significant beschouwd bij $p<0.05$. 


\section{Resultaten}

\subsection{Water karakteristieken}

De watertemperatuur $\left(14-22^{\circ} \mathrm{C}\right)$, saliniteit (28-31\%o), $\mathrm{pH}(8.2-8.7)$ en zuurstofgehalten (95-104\%) bleven gedurende de proef binnen de grenzen van waarden die als normaal kunnen worden beschouwd voor de Waddenzee in het voorjaar/zomer (Figuur 2). Ontwikkeling van deze parameters was in alle mesocosms hetzelfde en niet beïnvloed door de behandeling.
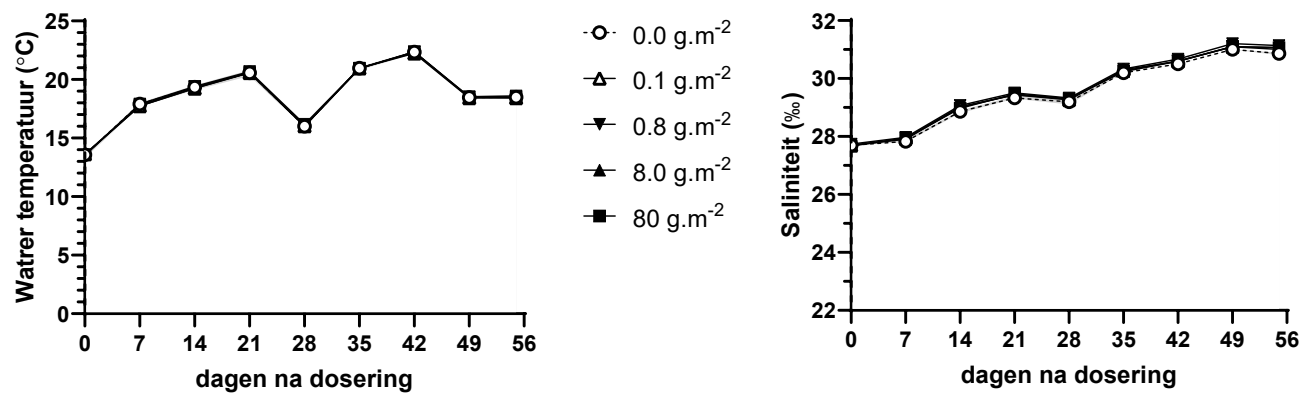

-0. $0.0 \mathrm{~g} \cdot \mathrm{m}^{-2}$

$\Delta 0.1 \mathrm{~g} \cdot \mathrm{m}^{-2}$

$\rightarrow 0.8 \mathrm{~g} \cdot \mathrm{m}^{-2}$

$\pm 8.0 \mathrm{~g} \cdot \mathrm{m}^{-2}$

- $80 \mathrm{~g} \cdot \mathrm{m}^{-2}$
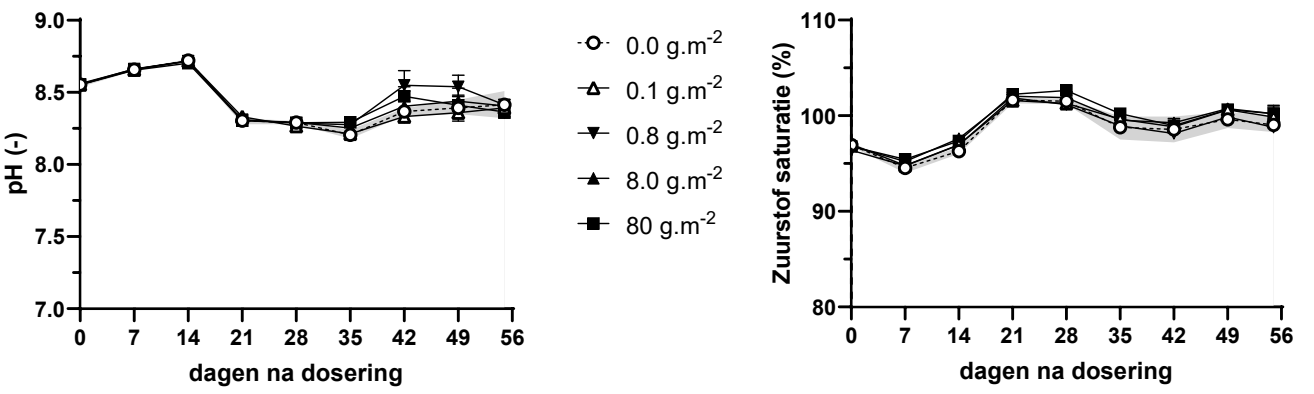

-0. $0.0 \mathrm{~g} \cdot \mathrm{m}^{-2}$

$\triangle 0.1 \mathrm{~g} \cdot \mathrm{m}^{-2}$

$\rightarrow 0.8 \mathrm{~g} \cdot \mathrm{m}^{-2}$

$\pm 8.0 \mathrm{~g} \cdot \mathrm{m}^{-2}$

- $80 \mathrm{~g} \cdot \mathrm{m}^{-2}$

Figuur 2. Temperatuur $\left({ }^{\circ} \mathrm{C}\right)$, saliniteit (\%o), $\mathrm{pH}$ en zuurstof $(\%)$ verzadigingsniveau van de waterkolom in de mesocosms gedurende de blootstellingsperiode. Weergegeven zijn gemiddelden van de drie replica's. De minimum-maximum range van is aangegeven door error bars voor de behandelingen, en als grijs veld voor de $0.0 \mathrm{~g} / \mathrm{m}^{2}$ mesocosms (Blanco's).

De gehalten van de opgeloste anorganische nutriënten, ortho-fosfaat, nitriet, nitraat en ammonium in de waterkolom van de mesocosms vertoonden ook geen relatie met de behandelingen (Figuur 3).

Fosfaatgehalten waren laag op het moment dat de dosering werd uitgevoerd en vertoonde een lichte stijging na dag 21 , die leidde tot een concentratie van ca. 0,2 mg $\mathrm{PO}_{4}-\mathrm{P} / \mathrm{L}$ aan het eind van de proef. Stikstofgehalten varieerden gedurende de gehele duur van de proef in alle mesocosms rond $1 \mathrm{mg} \mathrm{N} / \mathrm{L}$. Het stikstof was voor meer dan $90 \%$ aanwezig in de vorm van nitraat $\left(\mathrm{NO}_{3}\right)$, en de als ammonium $\left(\mathrm{NH}_{4}\right)$. Nitriet $\left(\mathrm{NO}_{2}\right)$ was slechts in minimale hoeveelheden aanwezig, vaak minder dan 0,001 mg N/L.
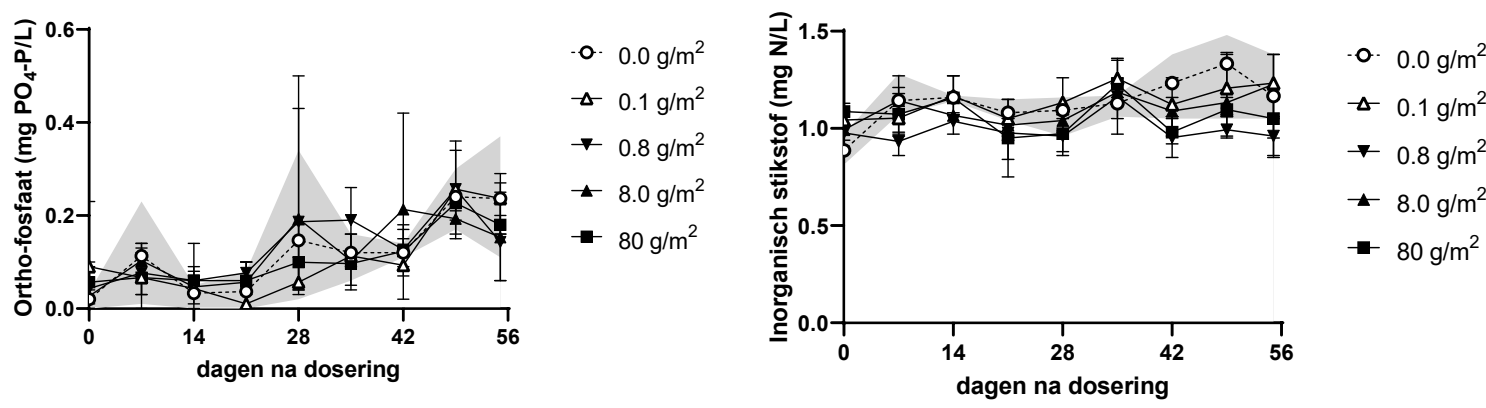

Figuur 3. Concentraties opgelost anorganisch fosfaat en stikstof in de waterkolom van de mesocosms gedurende de blootstellingsperiode. Weergegeven zijn gemiddelden van de drie replica's. De minimummaximum range van is aangegeven door error bars voor de behandelingen, en als grijs veld voor de 0.0 $\mathrm{g} / \mathrm{m} 2$ mesocosms (Blanco's). 


\subsection{Verdeling PS-korrels in sediment en water}

Na dosering bleef een deel van de korrels gedurende enkele uren gevangen in de oppervlaktespanning drijven, maar de volgende dag waren alle korrels van het wateroppervlak verdwenen. Gedurende de gehele looptijd van de proef werden korrels gesuspendeerd in de waterkolom waargenomen. Bij de eindbemonstering, 8 weken na de dosering, werd op basis van de hoeveelheden korrels die werden teruggevonden in het sediment van de hoogst gedoseerde mesocosms ruw geschat dat ca. $85 \%$ van de gedoseerde korrels zich in, of op het sediment bevond. Dit getal moet worden beschouwd als een grove schatting die gebaseerd is op een totaal bemonsterd sedimentoppervlak van 0,004 $\mathrm{m}^{2}$, zodat een vermenigvuldigingsfactor van 816 nodig was om de totale aantallen per mesocosm te berekenen. Circa $80 \%$ van de korrels in het sediment was aanwezig in de bovenste $5 \mathrm{~cm}$, en daarvan iets minder dan de helft in de bovenste $\mathrm{cm}$. Iets meer dan $10 \%$ van de korrels werd dieper dan $5 \mathrm{~cm}$ teruggevonden (Figuur 4).
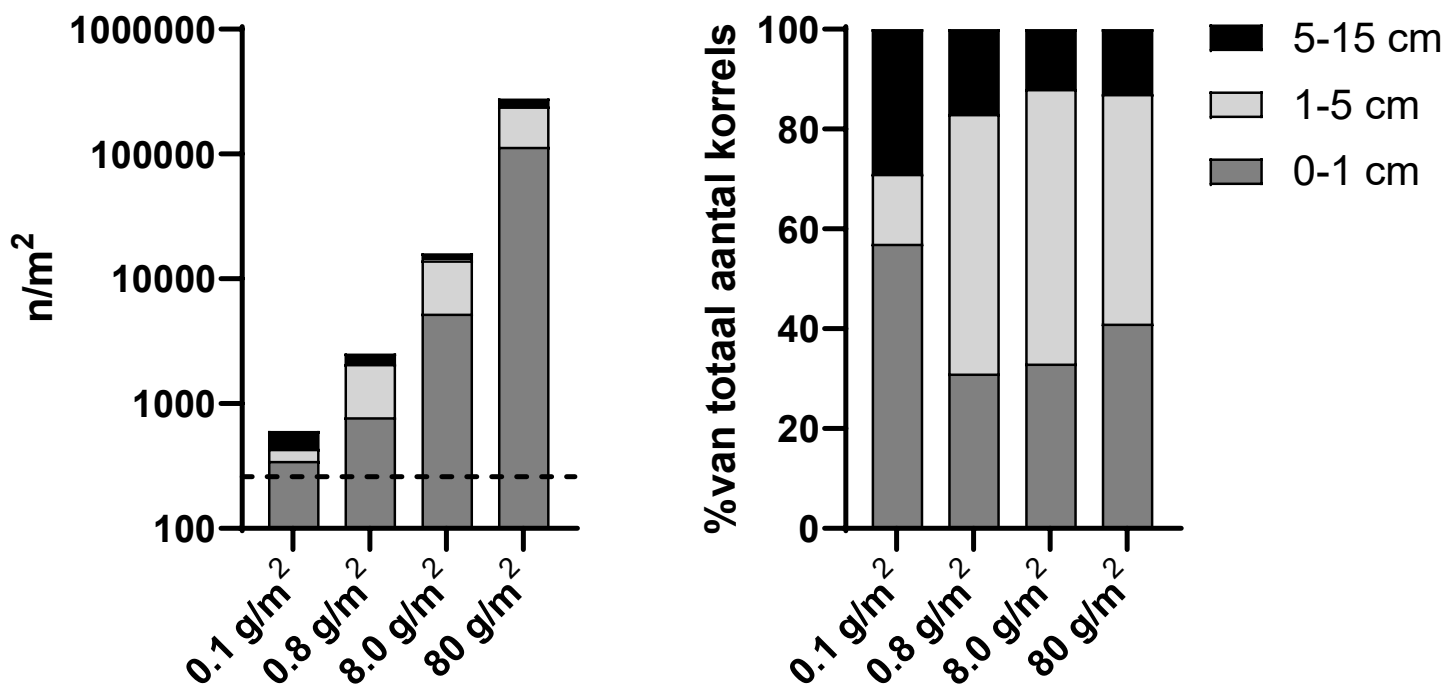

Figuur 4. Hoeveelheden PS-korrels op de dieptes $0-1 \mathrm{~cm}$ (top), 1-5 cm, en 5-15 cm (bodem) in sediment cores genomen aan het eind van de proef. De aantallen zijn links uitgedrukt per $\mathrm{m}^{2}$. Het totale monsteroppervlak bedroeg 0,004 $\mathrm{m}^{2}$ resulterend in een detectielimiet van $260 / \mathrm{m}^{2}$ zoals aangegeven door de horizontale stippellijn. Rechts uitgedrukt als percentage van het totaal aantal deeltjes. 


\subsection{Ontwikkeling biota}

\subsubsection{Planktongemeenschap}

\section{Fytoplankton}

Het chlorofyl-a gehalte van het water in de mesocosms varieerde tussen 1 en $20 \mu \mathrm{g} / \mathrm{L}$ (Figuur 5). De gemiddelde chlorofyl-a gehalten in de blanco's en de laagst gedoseerde mesocosms waren vanaf dag 14 vrijwel altijd hoger dan in de hoger gedoseerde mesocosms. Verschillen tussen behandelingen en controles waren echter niet statistisch significant.

Groenalgen domineerden de fytoplankton community samen met diatomeeën die een duidelijk kleiner aandeel hadden. $\mathrm{Na}$ dag 35 nam in de meeste mesocosms de hoeveelheid cyanobacteriën (blauwalgen) toe, zonder dat echter van een blauwalgen bloei sprake was. De dataset bevat geen indicaties dat de ontwikkeling van de fytoplankton gemeenschap is beïnvloed door de behandelingen.
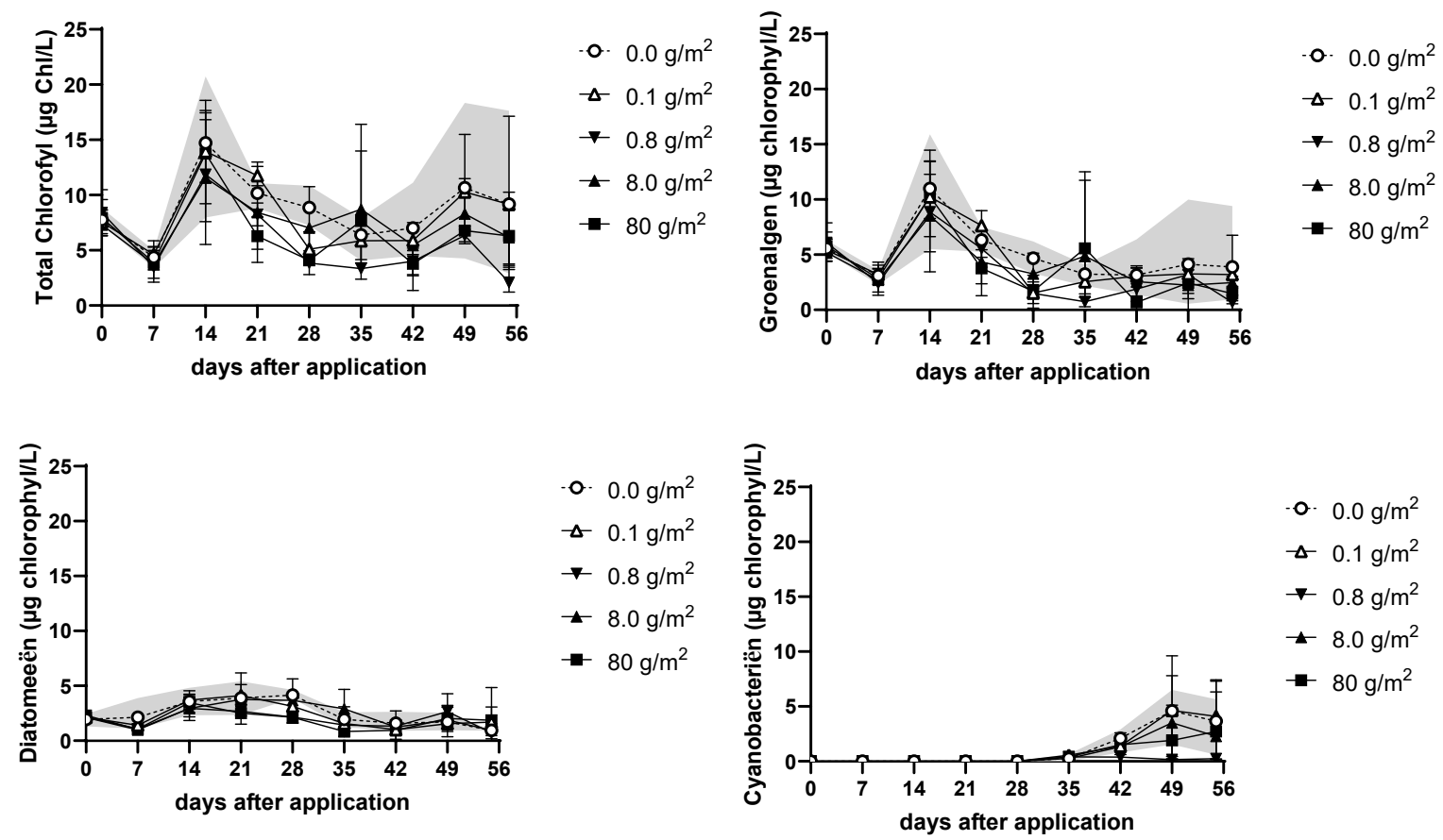

Figuur 5. Totaal chlorofyl-a gehalte in de waterkolom van de mesocosms als maat voor de fytoplankton biomassa, en het aandeel van groenalgen, diatomeeën en cyanobacteriën daarin. Weergegeven zijn gemiddelden van de drie replica's. De minimum-maximum range van is aangegeven door error bars voor de behandelingen, en als grijs veld voor de $0.0 \mathrm{~g} / \mathrm{m} 2$ mesocosms (Blanco's).

\section{Zoöplankton}

De zoöplanktongemeenschap in de mesocosms werd in aantallen gedomineerd door copepoden en hun larven (nauplii) (Figuur 6). De dichtheden adulte copepoden bereikten hun piek rond dag 35 met meer dan 50 individuen per liter in de meeste mesocosms. Daarna werden de aantallen geleidelijk minder, maar steeg wel het aantal nauplii. Dit patroon is globaal hetzelfde in alle mesocosms en toont geen indicaties dat het is beïnvloed door de behandelingen.

Tussen dag 21 en 28 stegen de aantallen adulte copepoden in de drie blanco mesocosms wel sneller dan in de met plastic gedoseerde mesocosms. Dit leidde op dag 28 tot een trend die een relatie met de behandeling suggereert, en tot statistisch significant lagere copepoden dichtheden in de $80 \mathrm{~g} / \mathrm{m}^{2}$ mesocosms ten opzichte van de blanco's (Figuur 6). Bij de volgende bemonstering, een week later, was dit verschil verdwenen. Of deze eenmalig waargenomen verschillen verband houden met de behandeling, of op toeval berusten is onduidelijk.

$\mathrm{Na}$ dag 28 verschijnen er veel larven van polychaete wormen in de waterkolom met een relatief grote spreiding tussen mesocosms, zonder indicatie dat de aantallen zijn beïnvloed door de behandeling. 

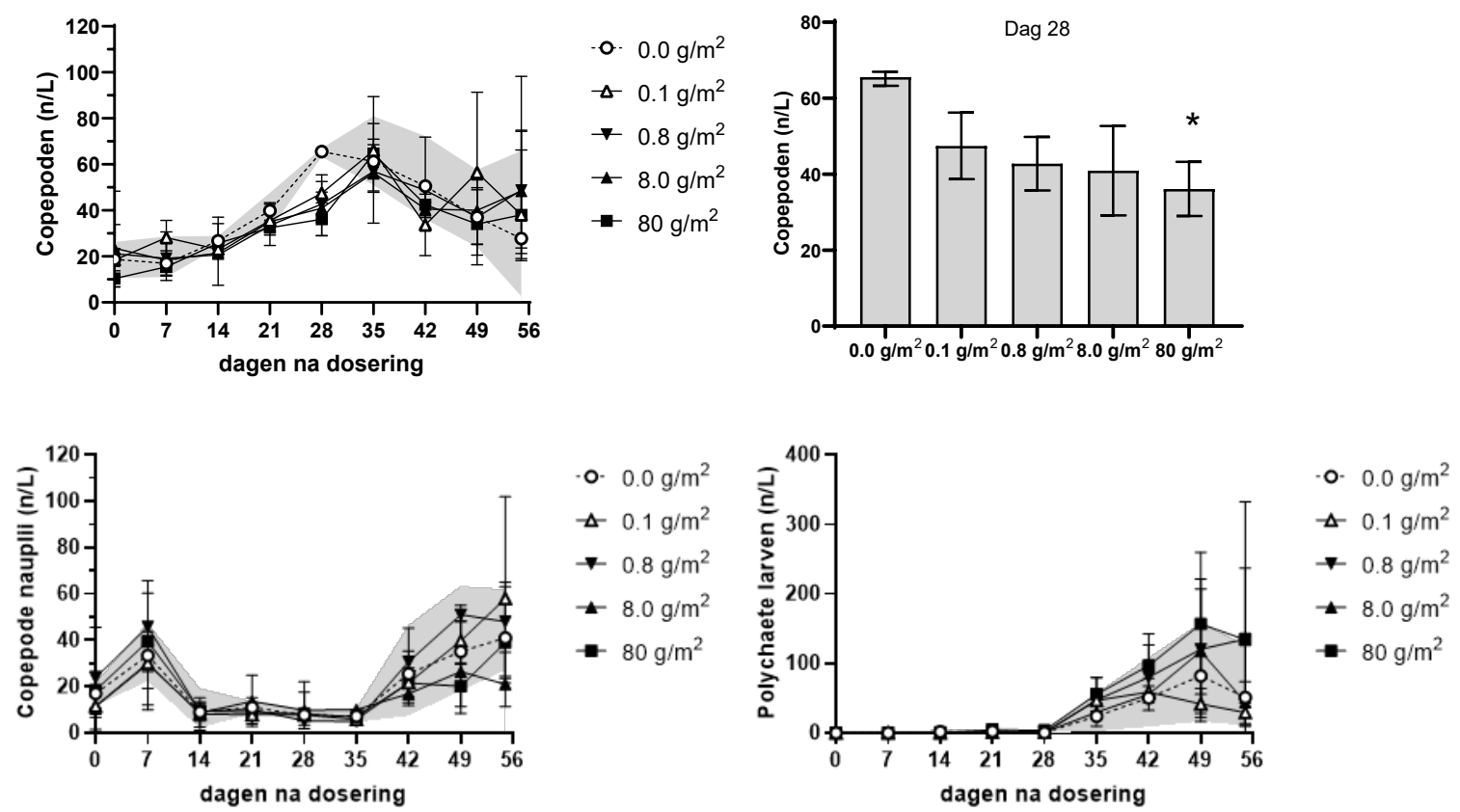

Figuur 6. Dichtheden van de numeriek belangrijkste zoöplankton groepen in het water van de mesocosms: adulte copepoden, copepoden larven (nauplii), en larven van polychaete wormen. Weergegeven zijn gemiddelden van de drie replica's. De minimum-maximum range van is aangegeven door error bars voor de behandelingen, en als grijs veld voor de $0.0 \mathrm{~g} / \mathrm{m} 2$ mesocosms (Blanco's).

\subsubsection{Perifyton}

De biomassa ontwikkeling van de sessiele algen op de uitgehangen glasplaatjes toonde geen effect van de behandeling (Figuur 7). Op dag 28 werd een hogere biomassa vastgesteld dan in de periode erna. Ook was tijdens de beginperiode de spreiding tussen replica mesocosms groter.
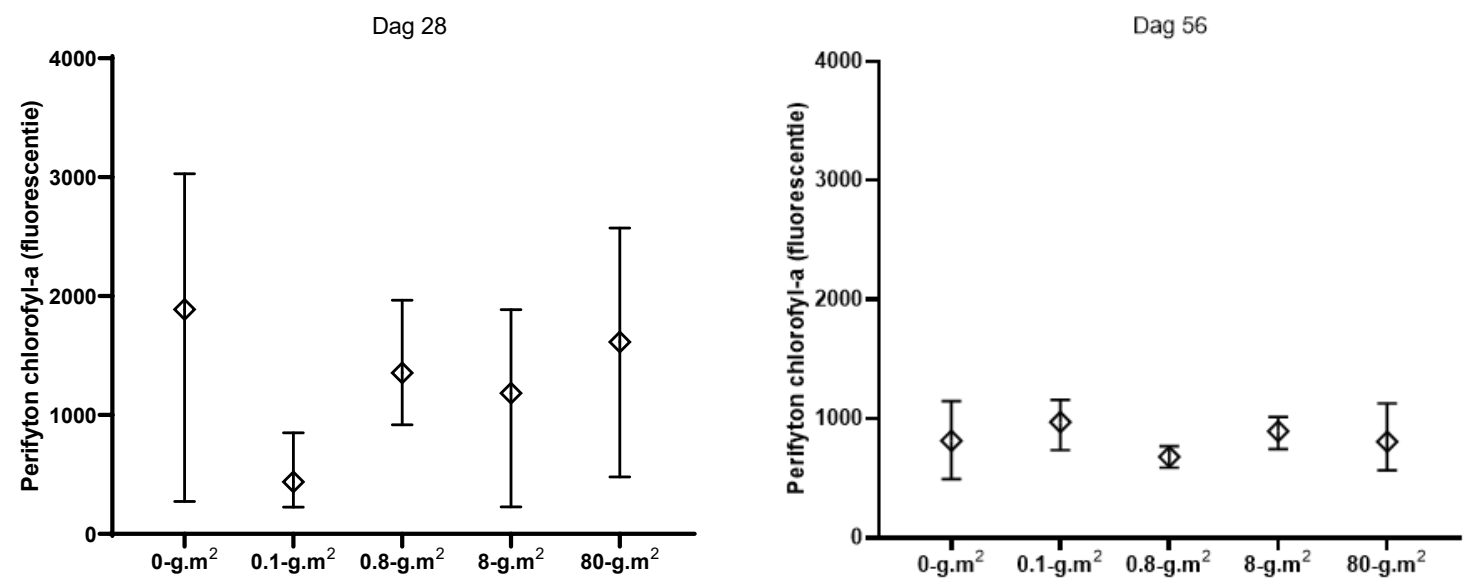

Figuur 7. Biomassa van sessiele algen (perfifyton) op glasplaatjes na 4 weken te zijn geïncubeerd in de mesocosms, uitgedrukt als fluorescentie eenheden. 


\subsubsection{Benthos gemeenschap}

Het sediment van de mesocosms bevatte rond de 20 soorten macro-evertebraten, bestaande uit wormen, schelpdieren, kreeftachtigen en neteldieren (m.n. anemonen). De aantallen soorten (species richness) en de biodiversiteit (diversity index en eveness - berekend volgens zowel de ShannonWiener als de Simpson methode) van de benthosgemeenschap was niet verschillend tussen blanco's en behandelde mesocosms bij de eindbemonstering (Figuur 8).
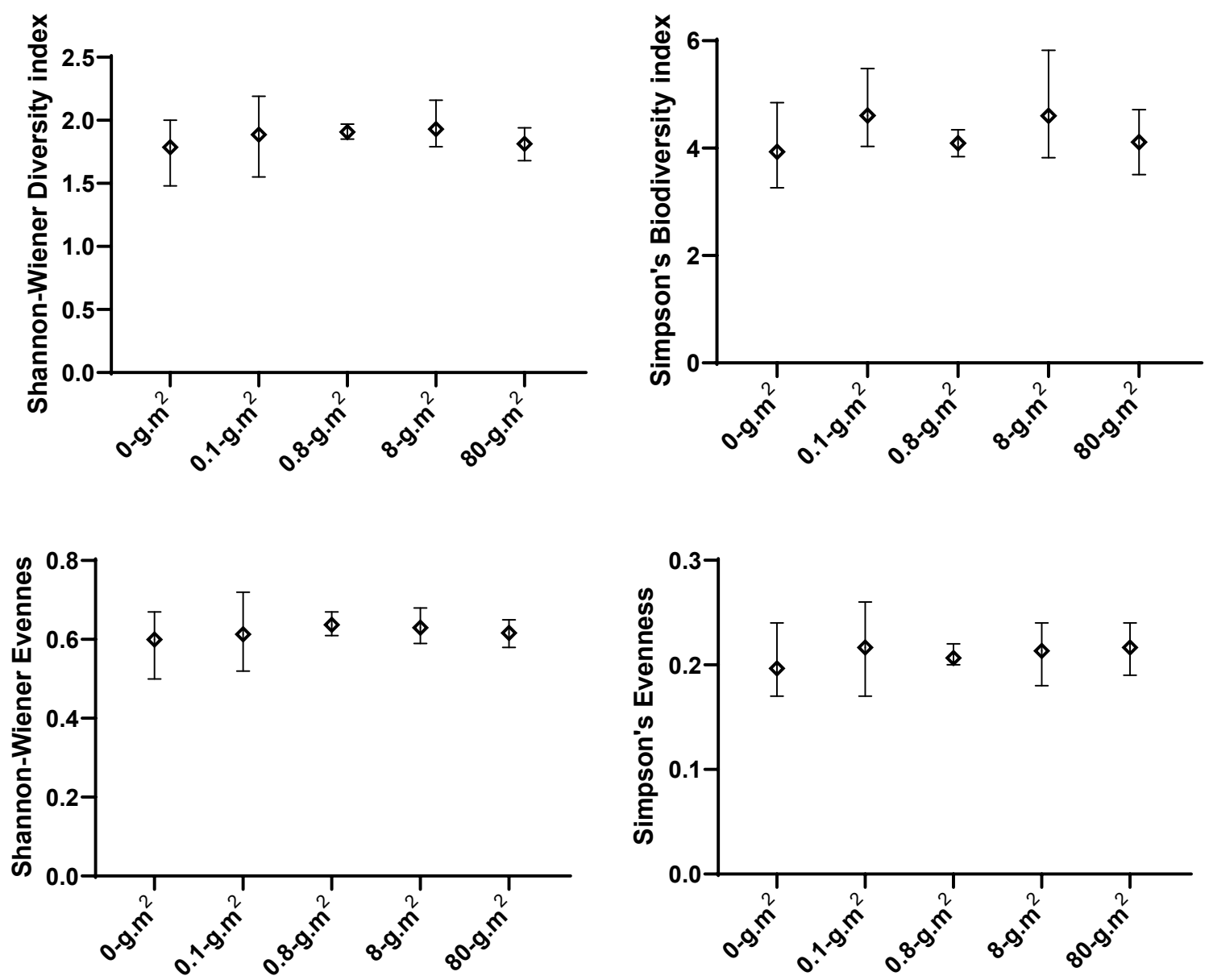

Figuur 8. Biodiversiteit (boven) en Evenness (onder) van de levensgemeenschap van benthische organismen in de mesocosms, berekend volgens de methode van Shannon-Wiener (links) en Simpson (rechts). 
Het totaal aantal benthische organismen van alle soorten samen toonde wel een respons op de behandeling (Figuur 9). De significant hoogste aantallen werden gevonden bij 0,8 g/m². Bij hogere blootstellingsconcentraties dalen deze aantallen weer. Dit patroon is ook aanwezig wanneer wormen en schelpdieren apart worden beschouwd.
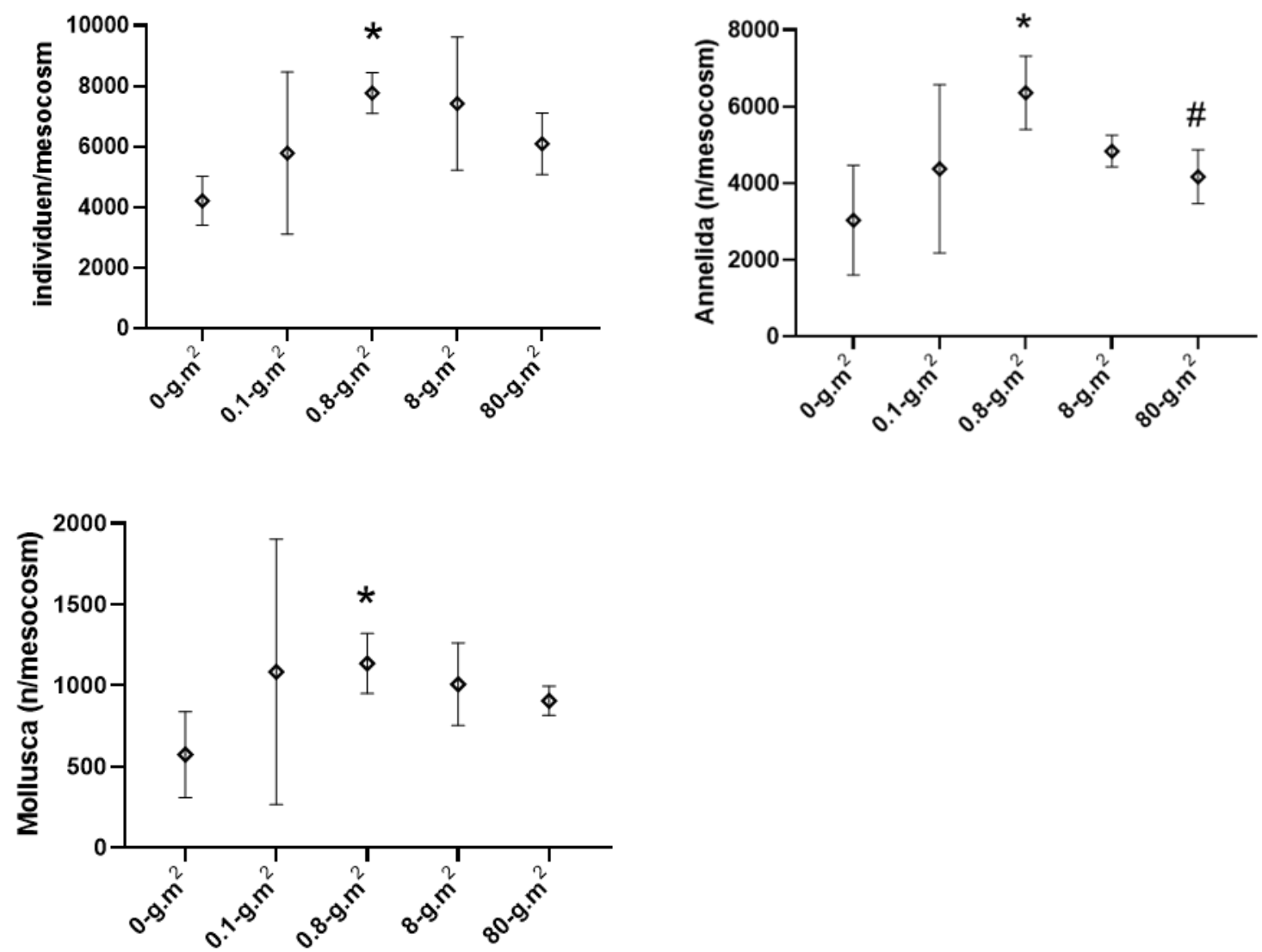

Figuur 10. Totale dichtheid aan bodemdieren (linksboven), dichtheid van wormen (Annelida, rechtsboven) en van schelpdieren (Mollusca, linksonder). '*' betekent significant $(p=<0,05)$ afwijkend van de $0 \mathrm{~g} / \mathrm{m2}$ mesocosms, '\#' betekent significant afwijkend van de $0,8 \mathrm{~g} / \mathrm{m} 2$ mesocosms.

De Capitellidae en Spionidae (Figuur 11) vormden de meest abundante groepen onder de wormen. Beiden zijn kleine borstelwormen. Capitellidae leven 'vrij' in het sediment, terwijl Spionidae kokers maken van zandkorrels en organisch materiaal. De Capitellidae volgden het patroon van de Annelida, met een optimum in de $0,8 \mathrm{~g} / \mathrm{m}^{2}$ behandeling, gevolgd door een significante afname ten opzichte van deze piek bij hogere concentraties. Bij de Spionidae is na $0,8 \mathrm{~g} / \mathrm{m}^{2}$ behandeling geen afname, maar stabilisatie zichtbaar, met een statistisch significant hogere dichtheid in de hoogst gedoseerde mesocosms.

Onder de schelpdieren waren juveniele mosselen (Mytilus edulis) en mesheften (Ensis sp.) de numeriek dominante groepen. Deze taxa vertoonden geen respons met de behandeling. Wadslakjes (Peringia ulvae) en juveniele kokkels (Cerastoderma edule) toonden een gelijke respons als de wormen; met een optimum rond $0,8 \mathrm{~g} / \mathrm{m}^{2}$ (Figuur 11). 

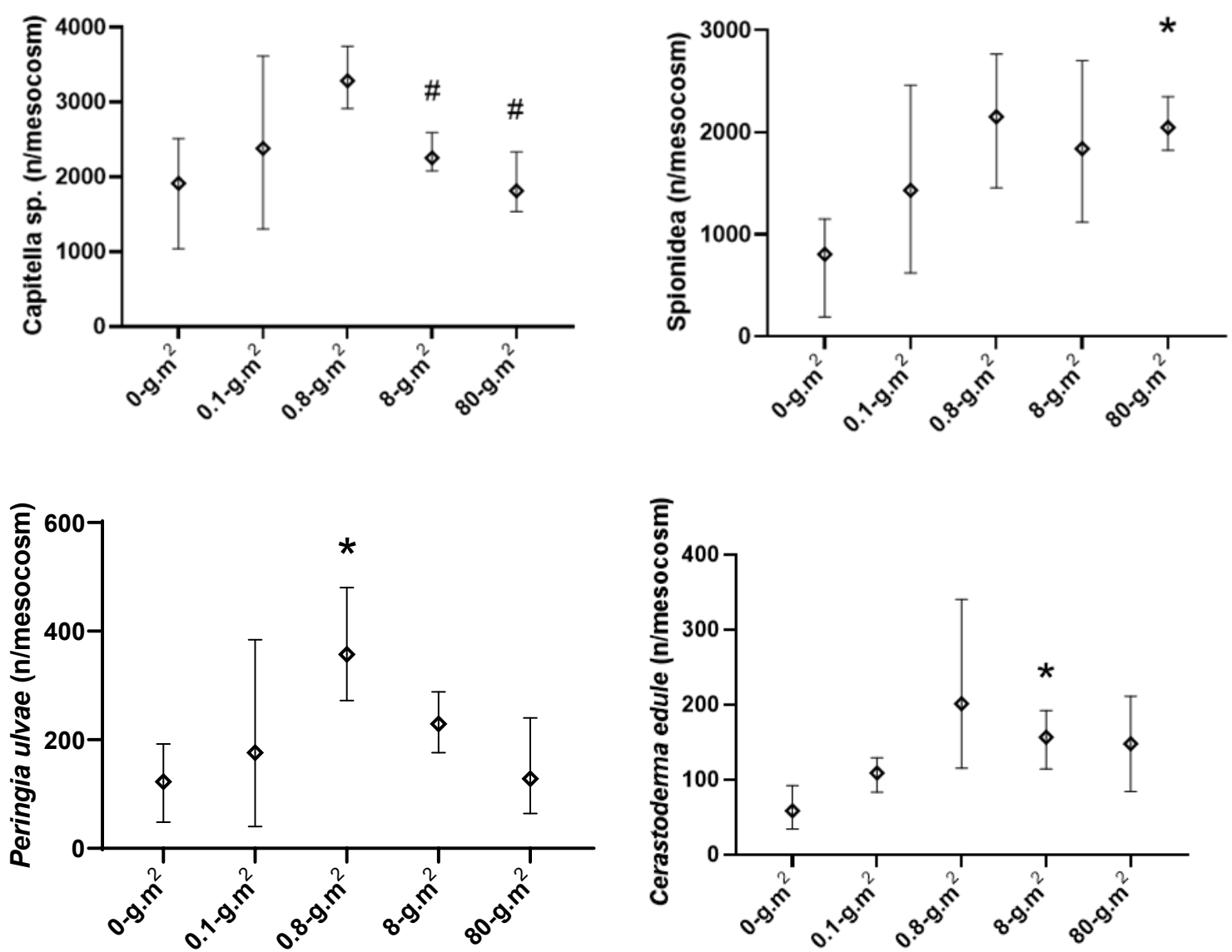

Figuur 11. Dichtheden van de borstelwormen Capitella sp. en Spionidae, en van de schelpdieren Peringia ulvae, het Wadslakje en Cerastoderma edule, de kokkel. ). '*' betekent significant $(p=<0,05)$ afwijkend van de $0 \mathrm{~g} / \mathrm{m} 2$ mesocosms, '\#'betekent significant afwijkend van de 0,8 $\mathrm{g} / \mathrm{m} 2$ mesocosms.

\section{Zeepokken}

Zeepokken die als larven met het zeewater in de mesocosms waren gebracht settelden zich op de wanden en op de beluchtingsbuis. Bij de eindbemonstering waren de aantallen per mesocosm gemiddeld lager in de doseringen boven de $0,1 \mathrm{~g} / \mathrm{m} 2$ dan in de controles (Figuur 12). Bij 0,8 g/m2 en $80 \mathrm{~g} / \mathrm{m} 2$ waren deze verschillen statistisch significant.



Figuur 12. Aantallen levende zeepokken (Balanidae) in de mesocosms tijdens de eindbemonstering 56 dagen na de dosering. 


\subsubsection{Geïntroduceerde soorten}

\section{Wadpieren}

Van de ingezette wadpieren werd bij de eindbemonstering per mesocosm gemiddeld $81 \%$ levend teruggevonden. Dit getal toonde geen relatie met de behandelingen. Ook het individueel lichaamsgewicht vertoonde geen significante verschillen tussen behandelingen. In alle mesocosms nam het gemiddelde lichaamsgewicht van de pieren tijdens de poef licht toe (Figuur 13).
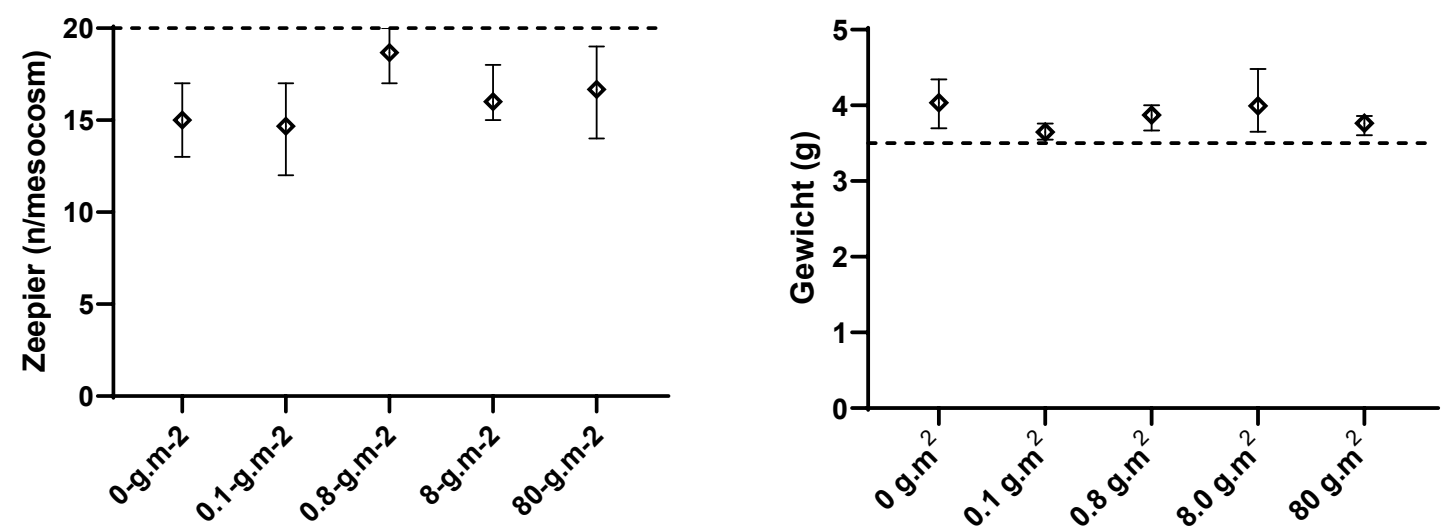

Figuur 13. Overleving en individueel gewicht van de geïntroduceerde wadpieren aan het eind van de proef. De horizontale stippellijnen geven de situatie weer tijdens de introductie van de dieren in de mesocosms. 


\section{Alikruiken}

Van de 50 geïntroduceerde alikruiken werd in elke mesocosm meer dan $95 \%$ levend teruggevonden bij de eindbemonstering (Figuur 14). In twee mesocosms bleken zelf 51 adulte alikruiken aanwezig, hoogstwaarschijnlijk het gevolg van een telfout bij het inzetten. In alle mesocosms waren de ingezette dieren ca. $2 \mathrm{~mm}$ gegroeid tot een schelplengte van rond $17 \mathrm{~mm}$, en een gewicht (schelp en vlees) van $1,7 \mathrm{gram}$ ten opzicht van $1,5 \mathrm{gram}$ bij inzetten. De conditiefactor was bij introductie $(0,24)$ iets hoger dan aan het eind van de proef $(0,22)$.

Er werden geen indicaties gevonden dat de alikruiken in de mesocosms beïnvloed waren door de behandelingen.
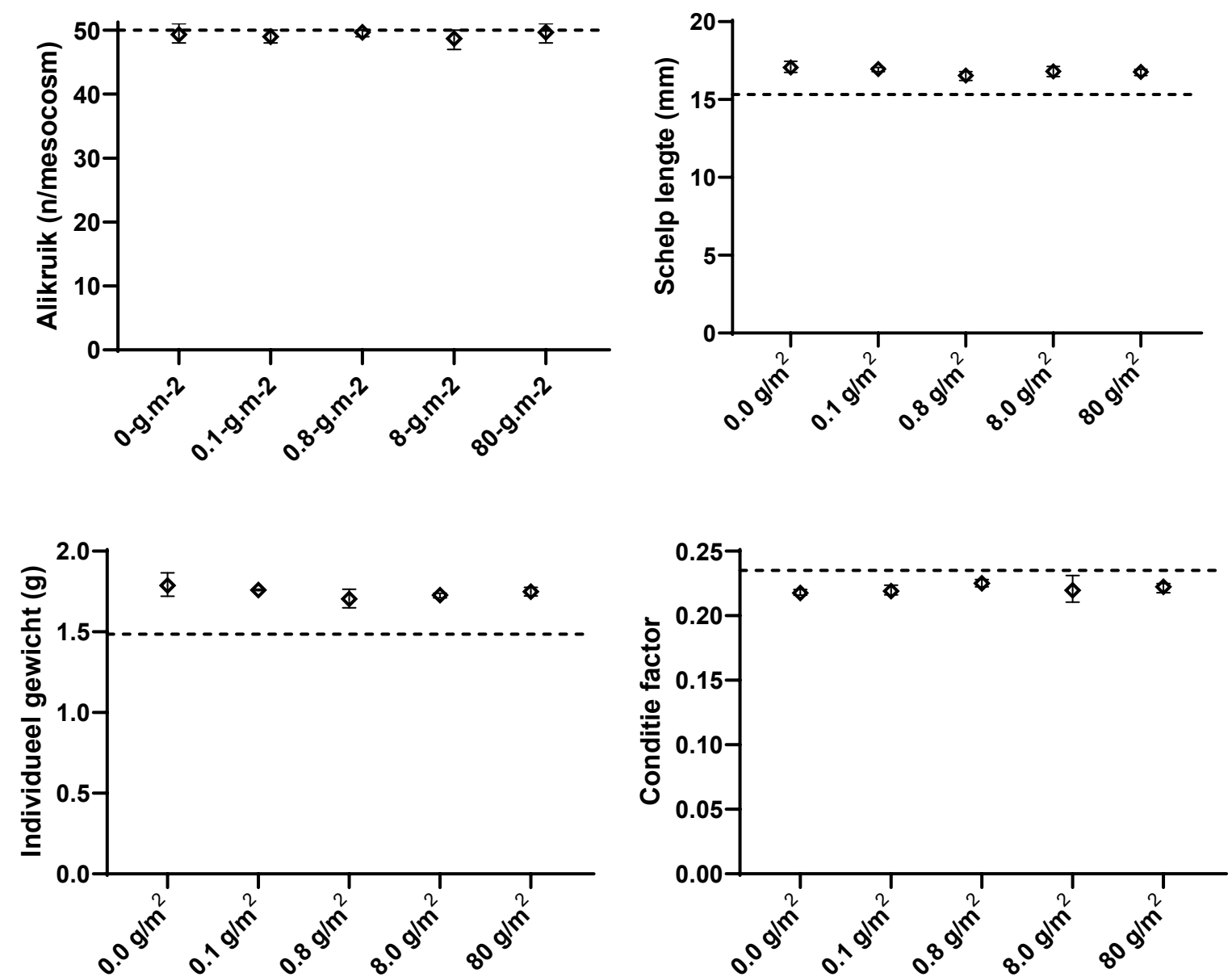

Figuur 14. Overleving, schelplengte, individueel gewicht (vlees + schelp) en conditie factor van de geïntroduceerde Alikruiken aan het eind van de proef. De horizontale stippellijnen geven de situatie weer tijdens de introductie van de dieren in de mesocosms. 


\section{Kokkels}

De overleving van de geïntroduceerde kokkels was gemiddeld $93 \%$ en vertoonde ook geen relatie met de behandeling (Figuur 15). Gedurende de proef nam de schelplengte met ruim $50 \%$ toe en verdrievoudigde het vleesgewicht, waardoor ook de conditiefactor verbeterde. Er werden geen significante verschillen tussen behandelingen vastgesteld.
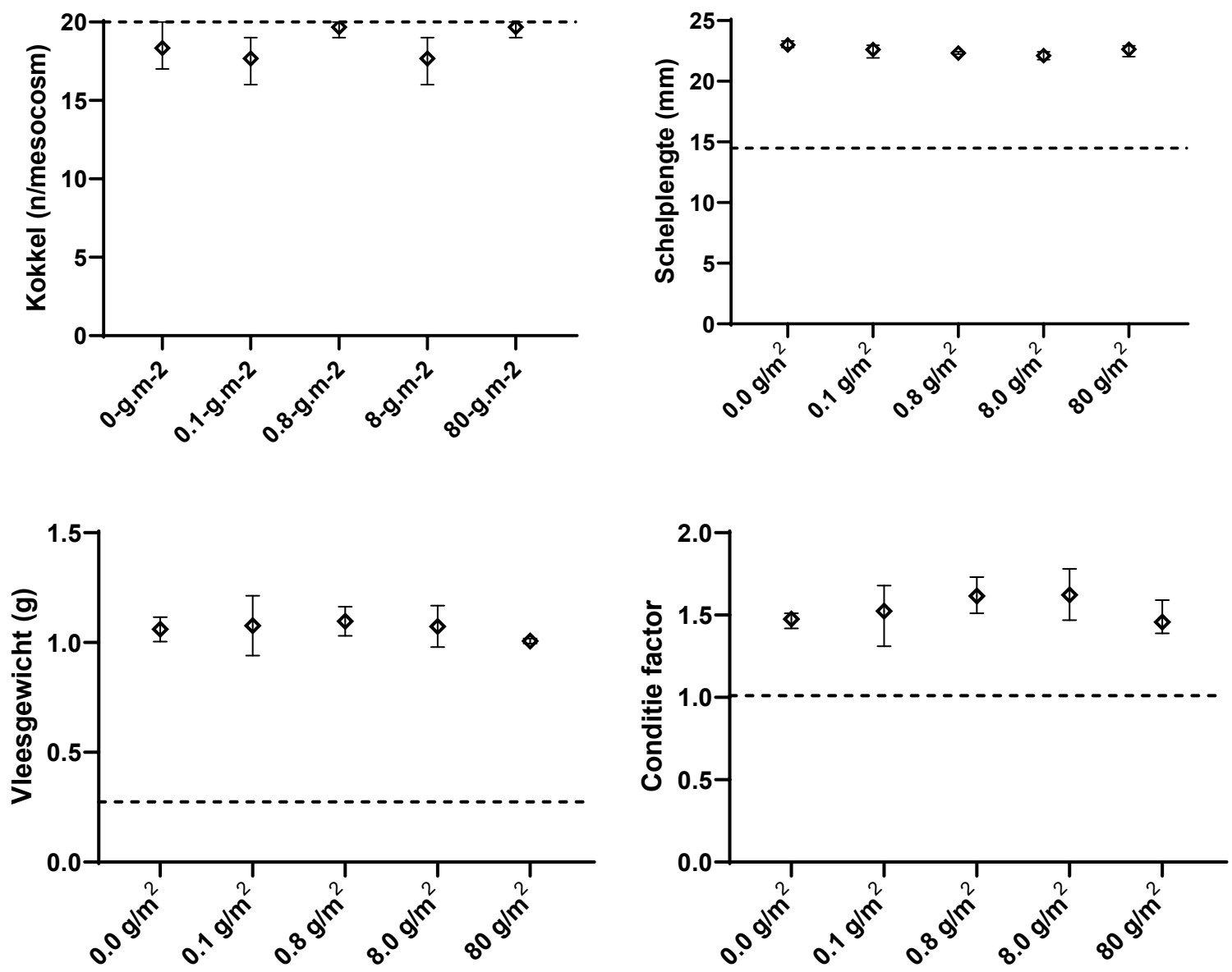

Figuur 15. Overleving, schelplengte, individueel vleesgewicht en conditie factor van de geïntroduceerde Kokkels aan het eind van de proef. De horizontale stippellijnen geven de situatie weer tijdens de introductie van de dieren in de mesocosms. 


\section{Mosselen}

Van de geïntroduceerde mosselen was per mesocosm gemiddeld $95 \%$ in leven tijdens de eindbemonstering. In alle mesocosms nam de schelplengte van de mosselen met ca. $7 \mathrm{~mm}$ toe tijdens de blootstellingsduur, terwijl het vleesgewicht ruim verdubbelde (Figuur 16). Deze gewichtstoename vertoonde geen duidelijke correlatie met de dosering, maar was wel significant $(p=0,007)$ groter in de hoogst gedoseerde mesocosms. De conditie factor toont een vergelijkbaar beeld, maar zonder significante verschillen.
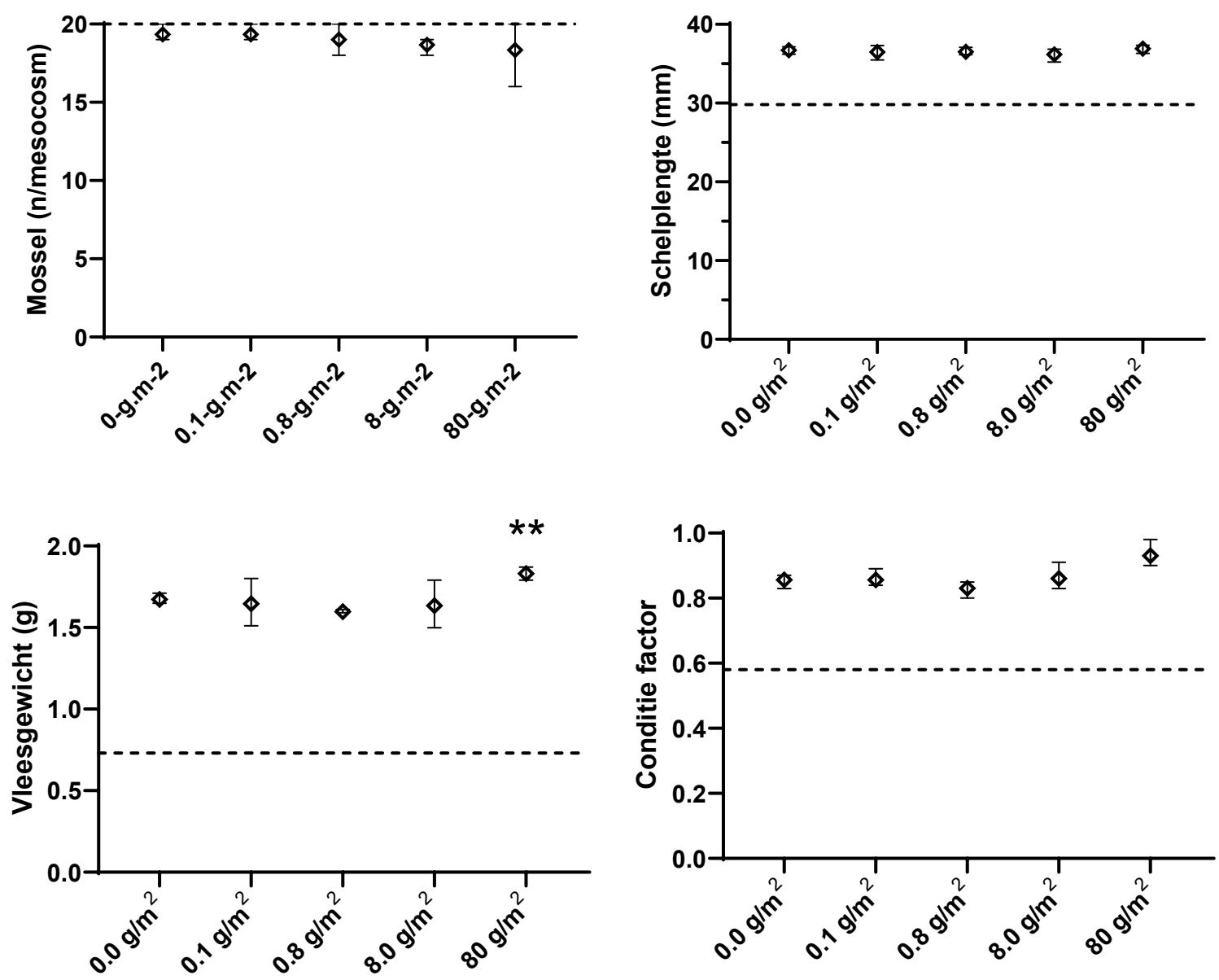

Figuur 16. Overleving, schelplengte, individueel vleesgewicht en conditie factor van de geïntroduceerde mosselen aan het eind van de proef. De horizontale stippellijnen geven de situatie weer tijdens de introductie van de dieren in de mesocosms. 
Van de ingezette juveniele tongetjes werd bij de eindbemonstering gemiddeld per mesocosm $96 \%$ levend teruggevonden, zonder verschillen tussen behandelingen. Alle teruggevangen tongetjes verkeerden in goede conditie. Sinds de introductie was de lengte ruim verdubbeld, en het lichaamsgewicht ongeveer vertienvoudigd (Figuur 17). De conditiefactor was wel iets lager dan toen de dieren vers uit de kwekerij kwamen, en toont een correlatie met de behandelingen; in de $0,8 \mathrm{~g} / \mathrm{m}^{2}$ en $80 \mathrm{~g} / \mathrm{m}^{2}$ mesocosms was de conditiefactor bij de eindbemonstering significant lager (respectievelijk $\mathrm{p}=0,027$ en 0,032 ) dan in de blanco mesocosms.
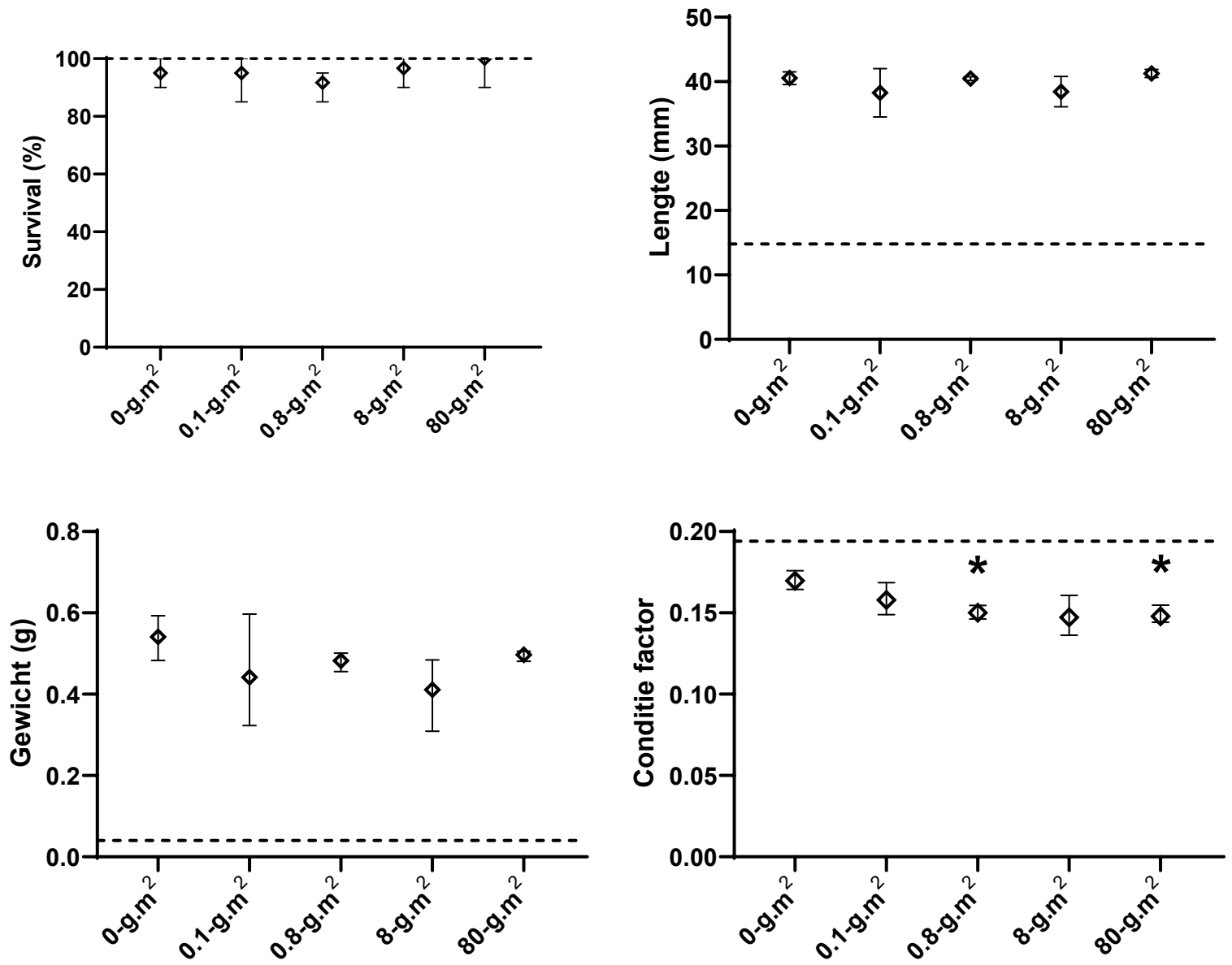

Figuur 17. Overleving, lichaamslengte, individueel gewicht en conditie factor van de geïntroduceerde juveniele Tongen aan het eind van de proef. De horizontale stippellijnen geven de situatie weer tijdens de introductie van de dieren in de mesocosms. '*' betekent significant $(p=<0.05)$ afwijkend van de $0 \mathrm{~g} / \mathrm{m} 2$ mesocosms. 


\subsection{Interacties biota met PS-korrels}

\subsubsection{Schelpdieren}

In het lichaam van de mosselen werden geen PS-korrels aangetroffen. De korrels werden wel in grote hoeveelheden aangetroffen in het slib dat zich tussen de mosselen verzamelde en dat voor een belangrijk deel uit faeces en pseudofaeces bestaat. Pseudofaeces zijn de oneetbare materialen die de mossel uit het water filtert, maar niet inslikt. Deze worden als pellets 'uitgespuugd'.

De totale hoeveelheid geproduceerde (pseudo)faeces lijkt hoger in de hoogst gedoseerde mesocosms, maar verschillen zijn niet statistisch significant (Figuur 18).

In alle mesocosms met uitzondering van de blanco's, bevatte de pseudofaeces PS-korrels. De aantallen liepen uiteen van gemiddeld ca. 1 korrel per gram drooggewicht in de laagst gedoseerde mesocosms, tot ca. 3000 korrels per gram bij de hoogste dosering.

Dag 0-7

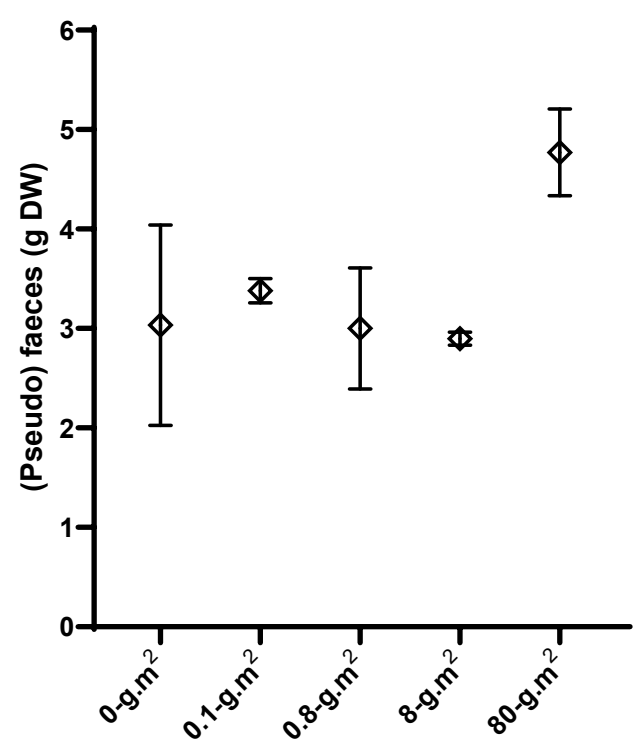

Dag 21-28

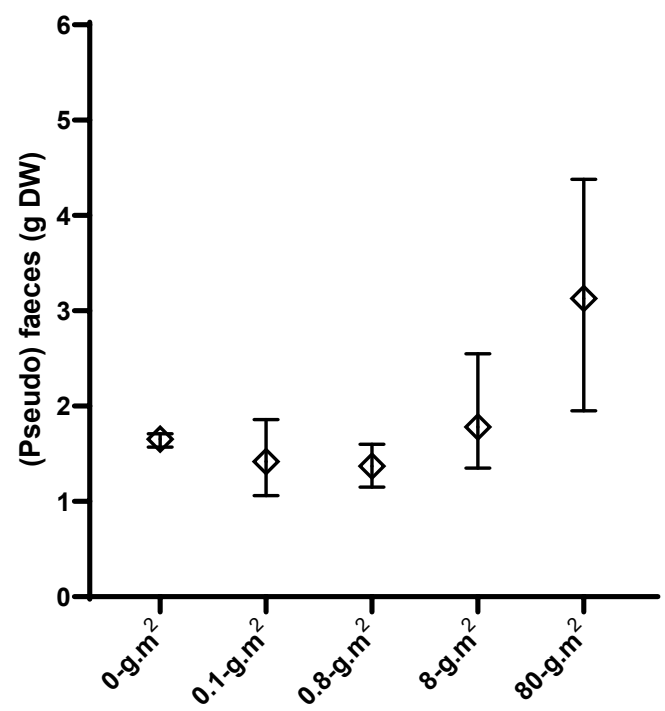

Dag 0-7

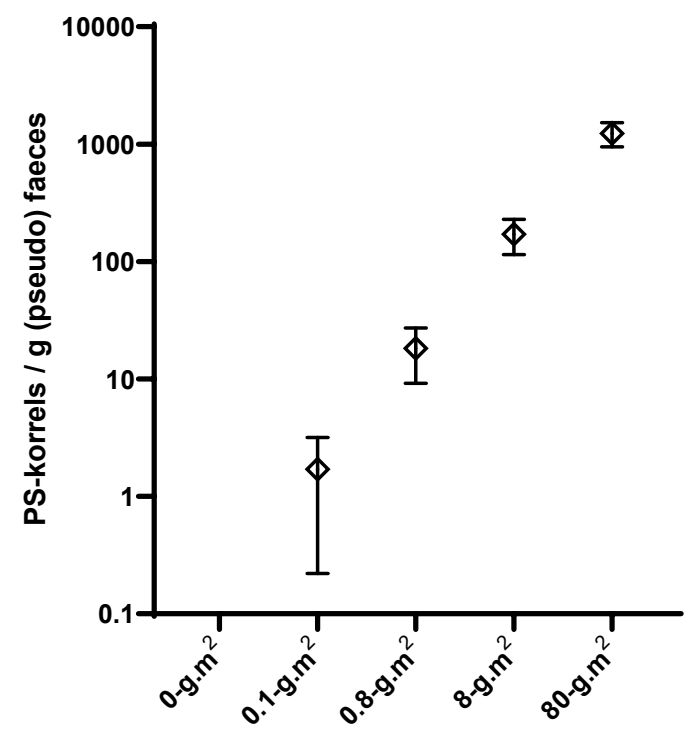

Dag 21-28

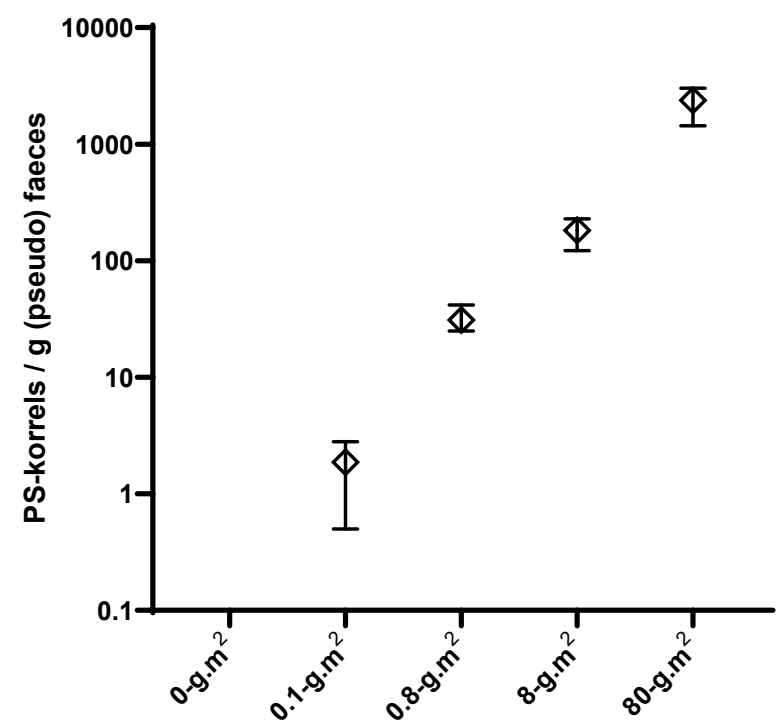

Figuur 18. Door mosselen in de mesocosms geproduceerde hoeveelheid (pseudo)faeces (links) en de hoeveelheid PS-korrels daarin uitgedrukt per gram (rechts), voor de periodes tussen dag 0 en 7 (boven) en tussen dag 21 en 28 (onder). 


\subsubsection{Wormen}

In het uitgepoepte sediment van de wadpieren die bij de eindbemonstering werden verzameld werden PS-korrels teruggevonden in de $0,8 \mathrm{~g} / \mathrm{m}^{2}$ mesocosms en hoger. Bij de hoogste dosering bevatte een wadpier gemiddeld ca. 10 PS-korrels, met uitschieters van meer dan 30 korrels per pier (Figuur 19). Het sediment dat de pieren uit de hoogst gedoseerde mesocosms uitpoepten bevatte tussen 3,7 en 13 PS-korrels per gram. Dit ligt in dezelfde orde van grootte als de 1,3 tot 9,2 korrels per gram die in de bovenste $\mathrm{cm}$ van het sediment in dezelfde mesocosms aanwezig was. Blijkbaar vermijden de wadpieren de PS-korrels niet tijdens het foerageren.

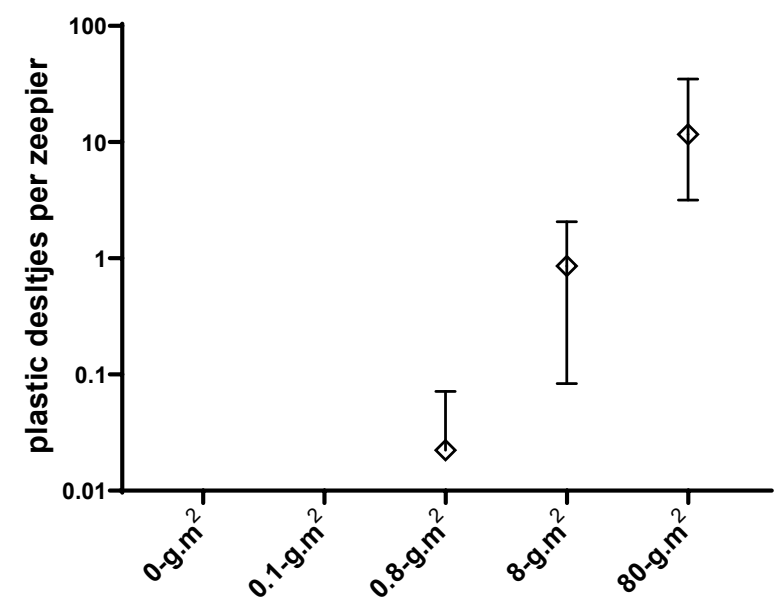

Figuur 19. Gemiddeld aantal PE-korrels dat aanwezig was in de darmen van wadpieren aan het eind van de proef.

\subsubsection{Vissen}

Bij de eindbemonstering werden PS-korrels aangetroffen in respectievelijk $2 \%$ ( 1 van 56 ), $3 \%$ ( 2 van 58 ) en $17 \%$ (10 van 60) van de tongetjes uit de 0,8, 8,0 en $80 \mathrm{~g} / \mathrm{m}^{2}$ mesocosms. De 57 tongetjes uit de $0,1 \mathrm{~g} / \mathrm{m}^{2}$ mesocosms hadden geen korrels in te maagdarmkanaal.

Het maximaal aantal korrels per visje was 7 (Figuur 20A) en werd aangetroffen in een mesocosm met de hoogste dosering. In vijf andere visjes uit deze mesocosms waren 2 of 3 korrels aanwezig en in vier andere individuen werd 1 korrel gevonden. In totaal bevatten de 10 visjes met plastics uit de 80 $\mathrm{g} / \mathrm{m}^{2}$ mesocosms 26 PS-korrels. De drie visjes met plastic uit de lager gedoseerde mesocosms hadden elk 1 korrel in de ingewanden.

De vissen met plastics in de ingewanden tijdens de eindbemonstering waren qua lengte, gewicht, conditie of uiterlijk niet afwijkend van de dieren die op dat moment geen plastic bevatten. Er werden ook geen aanwijzingen gevonden dat de korrels substantiële problemen, zoals verstopping, in het maag-darm kanaal van de visjes veroorzaakten, of dat de korrels ophoopten in het maagdarmkanaal. Bij het onderzoek werden in de darmen ook huisjes van wadslakjes (Figuur 20B en D) en schelpenresten van kokkels (Figuur 20C) aangetroffen met een grotere diameter dan de PS-korrels. De situatie weergegeven in Figuur 20D, waarbij de PS-korrel de overgang markeert van een volle naar een lege darm kan er mogelijk op duiden dat de opname van het plastic tot een tragere darmpassage leidt. Dit zou het subtiele effect op de conditie factor (Figuur 17) kunnen verklaren. 


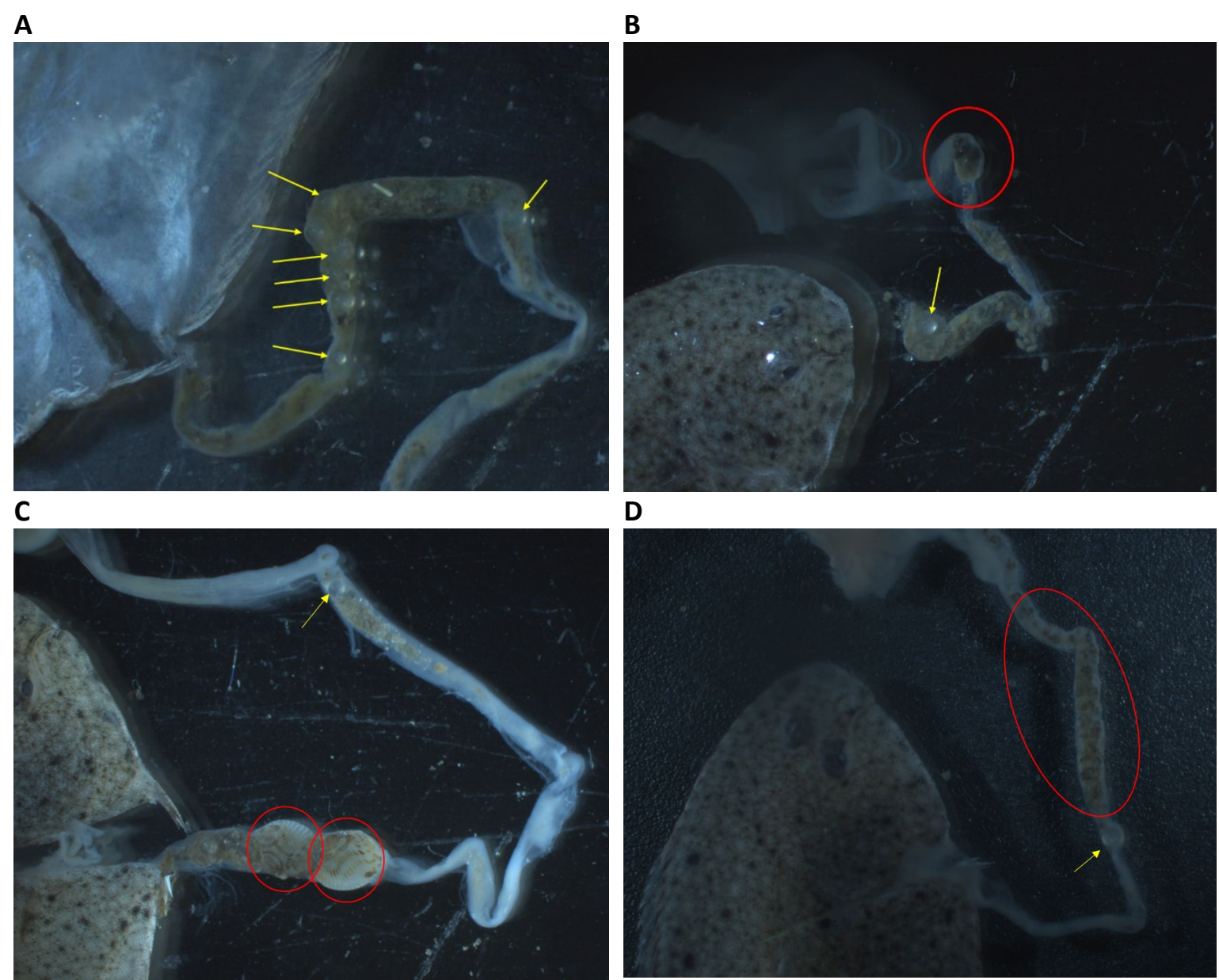

Figuur 20. Uitgeprepareerde darmen van een juveniele tong uit de mesocosms. De darm is losgesneden bij de keel, de uitgang van de darm (anus) is nog met het lichaam van de vis verbonden. De gele pijlen wijzen naar de ingeslikte PS-korrels. In de rode cirkels zijn schelpresten zichtbaar van wadslakjes (B en $D$ ) en kokkels (C). 


\section{Discussie en conclusies}

\subsection{Vertaalbaarheid naar veldsituatie}

De situatie in de mesocosms kan om meerdere redenen worden beschouwd als een worst-case situatie ten opzichte van de veldsituatie. Omdat het stagnante systemen betreft zonder waterverversing is herstel van een aangetaste populatie door herkolonisatie in de mesocosms niet mogelijk. In een veldsituatie zal bijvoorbeeld het volledig stilvallen van de reproductie van een soort in een gebied niet zichtbaar worden als pelagische larven van andere locaties met waterstromen worden aangevoerd. Dezelfde waterbeweging zal ervoor zorgen dat in de veldsituatie de PS-korrels waarschijnlijk minder lang op één locatie blijven. In de mesocosms bleef de blootstelling aan zowel bezonken als aan gesuspendeerde korrels gedurende de blootstellingsperiode ongewijzigd, terwijl verwacht mag worden dat in de veldsituatie zeker de gesuspendeerde deeltjes snel verspreid zullen worden.

Tenslotte vertonen de omstandigheden in de mesocosms minder variatie dan in het veld en is het in mesocosms mogelijk om Blanco en blootgestelde situaties te repliceren. Hierdoor is het onderscheidend vermogen van een mesocosm studie hoog vergeleken bij het meeste veldonderzoek; effecten die zichtbaar worden in een mesocosm studie zullen dus niet altijd aantoonbaar zijn in een veldsituatie. Waarmee niet gezegd is dat zij daar ook geen rol spelen op het functioneren van het ecosysteem.

De mesocosm heeft natuurlijk ook zijn restricties. Zo kunnen alleen effecten worden vastgesteld op soorten/levensgemeenschappen die in de mesocosms aanwezig zijn. Zo was er in deze studie alleen een benthische vissoort (tong) aanwezig, omdat er ten onrechte van werd uitgegaan dat alle korrels zich op de bodem zouden verzamelen. Het is niet uit te sluiten dat pelagische vissen gevoeliger zijn voor de PS-korrels dan de tongen (zie paragraaf 4.3 voor meer uitleg), waardoor het effect op vissen in deze studie zou worden onderschat.

Tenslotte was de looptijd van de studie beperkt tot 56 dagen, en werd alleen gebruik gemaakt van verse PS-korrels. Mogelijk worden effecten van langere blootstelling en/of van verouderde PS-korrels onderschat. Hier zijn echter geen directe aanwijzingen voor gevonden.

\subsection{Verspreiding van de PS-korrels in het milieu}

Gedurende de gehele proefperiode van 56 dagen werden er gesuspendeerde korrels in de waterkolom van de mesocosms waargenomen. Op basis van de sediment bemonsteringen kon een grove schatting gemaakt worden dat dit ca. $15 \%$ van de totale hoeveelheid gedoseerde korrels betrof. De korrels die wel op het sediment belanden kwamen voor een deel door de activiteit van bodembewonende organismen (in de mesocosms speelt andere verstoring van het sediment namelijk geen rol) in diepere sedimentlagen terecht.

De korrels werden verder aangetroffen in de ingewanden van vissen en wadpieren. De schelpdieren in de mesocosms hadden geen PE-korrels in de ingewanden en ook in de veldmonsters werden ze niet in schelpdieren aangetroffen. Waarschijnlijk zijn de korrels te groot om te worden ingeslikt door deze dieren die doorgaans voedseldeeltjes (vooral microalgen) eten in de grootteklasse van 4-40 $\mu \mathrm{m}$ (Strohmeier et al., 2012). Hoge dichtheden werden wel gevonden in de (pseudo)faeces van mosselen.

\subsection{Ecologische effecten van de PS-korrels}

In de mesocosm studie ontstonden effecten na de dosering van de PS-korrels. Statistisch significant waren een eenmalig lagere copepoden dichtheid in de $80 \mathrm{~g} / \mathrm{m}^{2}$ mesocosms; lagere dichtheden zeepokken vanaf $0,8 \mathrm{~g} / \mathrm{m}^{2}$; een piek in de dichtheid van schelpdieren en wormen in de $0,8 \mathrm{~g} / \mathrm{m}^{2}$ mesocosms voor sommige soorten gevolgd door een afname bij hogere concentraties; een hogere dichtheid van de wormen Spionidae sp. in de $80 \mathrm{~g} / \mathrm{m}^{2}$ mesocosms; een hoger vleesgewicht van 
mosselen in de $80 \mathrm{~g} / \mathrm{m}^{2}$ mesocosms; en een lagere conditie factor van de tong uit de $0,8 \mathrm{~g} / \mathrm{m}^{2}$ en de $80 \mathrm{~g} / \mathrm{m}^{2}$ mesocosms.

In de laagste test concentratie $\left(0,1 \mathrm{~g} / \mathrm{m}^{2}\right)$ werden geen statistisch significante afwijkingen van de blanco's gevonden. Deze concentratie komt overeen met het scenario dat alle door MSC-Zoe verloren PS-korrels homogeen zijn verspreid op een oppervlak van $10 \%$ van de Nederlandse Waddenzee. Dit betreft dan ca. 326 PS-korrels per $\mathrm{m}^{2}$. De volgende concentratie waarbij wel statistisch significante effecten zijn gevonden ligt een factor 10 hoger $\left(0,8 \mathrm{~g} / \mathrm{m}^{2}\right)$, ca. 3260 PS-korrels per $\mathrm{m}^{2}$.

De PS-korrels veroorzaakten geen zichtbare sterfte, substantiële achteruitgang in conditie van organismen, of veranderingen in de biodiversiteit. Wel lijken lage concentraties PS-korrels (tot 0,8 $\mathrm{g} / \mathrm{m}^{2}$ ) de productiviteit van het bodemleven te stimuleren. Welk mechanisme hierachter zit is nog onduidelijk. Mogelijk speelt het negatieve effect op de zeepokken een rol. Zeepokken voeden zich namelijk met zoöplankton dus ook met de pelagische larven van de bodembewonende soorten. De waargenomen stimulatie van het bodemleven in de hogere plastic concentraties zou dus het gevolg kunnen zijn van verminderde predatiedruk op de larven. De zoöplanktondichtheden tonen echter geen relatie met de aantallen zeepokken in de mesocosms.

Bij concentraties vanaf $8 \mathrm{~g} / \mathrm{m}^{2}$ wordt de stimulatie van het bodemleven teniet gedaan, mogelijk ondervinden deze soorten nu hinder van de korrels. In de hoogste testconcentratie zijn de dichtheden bodemdieren in vrijwel alle gevallen weer vergelijkbaar met de blanco's.

Voor de volledigheid wordt nog benadrukt dat deze waarnemingen niet zijn beïnvloed door (predatie door) de vissen; die bevonden zich namelijk in een andere serie mesocosms.

Effect van microplastics op de benthische levensgemeenschap is eerder aangetoond in een lang lopend zoetwater experiment (Redondo-Hasselerharm et al., 2020). Hier werd een significant effect gevonden in de hoogste blootstellingsconcentratie ( $5 \% \mathrm{w} / \mathrm{w})$. Dit zou gelijk staan aan een dosering van de mesocosms met $12 \mathrm{~kg}$ PS-korrels/m2, $150 \times$ hoger dan de hoogste concentratie die in dit project werd getest. Dergelijke extreem hoge doseringen hebben grote invloed op de leefomgeving, in dit geval op de samenstelling van het sediment.

Wadpieren slikken sediment in zonder enige aanwijzing dat zij daarbij de PS-korrels (kunnen) vermijden. Er werden geen effecten van de opname van de PS-korrels op de wadpieren vastgesteld. In eerdere aquarium studies zijn wel negatieve effecten van PS-microplastics op de groei van wadpieren gevonden (Besseling et al., 2013). Dit betrof echter plastic concentraties van 7,4 \% (w/w). In onze mesocosmstudie zou dat neerkomen op een dosering van meer dan $17 \mathrm{~kg}$ PS-korrels $/ \mathrm{m}^{2}$; ruim 220 x hoger dan de hoogst gehanteerde dosering $\left(80 \mathrm{~g} / \mathrm{m}^{2}\right)$ in deze studie. De effecten die dan optreden zijn waarschijnlijk het gevolg van de verdunning van het voedselrijke sediment met oneetbare plastic korrels (Besseling et al., 2013). Een dergelijke verandering van leefomgeving kan bij dit soort extreem hoge plastic concentraties verwacht worden.

De mesocosm studie maakt ook duidelijk dat vissen (tong in dit geval) de korrels kunnen inslikken. Bij deze kleine vissen is het niet uitgesloten dat de korrels als potentieel voedsel werden gezien en daarom bewust zijn ingeslikt. Echter, in de hoogste concentratie had 'slechts' $17 \%$ van de visjes PSkorrels in de ingewanden tijdens de eindbemonstering, terwijl de vissen in deze mesocosms constant omringd waren door meer dan 30 korrels per $\mathrm{cm}^{2}\left(325.900 / \mathrm{m}^{2} ;\right.$ Tabel 1$)$.

Juist kleine visjes zoals in de proef werden gebruikt zijn in theorie gevoelig voor het ontstaan van verstoppingen omdat de PS-korrels relatief groot zijn ten opzichte van de darmdiameter. Er zijn echter geen ophopingen van PS-korrels in het maag-darmkanaal aangetroffen, wat betekent dat ingeslikte korrels het lichaam via de natuurlijke weg verlaten; ze zijn immers te groot om de darmwand te passeren. Ingeslikte korrels kunnen wel tot een vertraagde darmpassage van het voedsel hebben geleid. Dit zou de waargenomen subtiele afname van de conditiefactor van de vissen uit de hoger gedoseerde mesocosms kunnen verklaren. Bij dieren met een grotere darmdiameter zal dit effect naar verwachting veel kleiner zijn. Het is daarom onwaarschijnlijk dat bij een langere blootstellingsperiode, waarin de visjes snel groter zouden worden, ernstiger effecten gevonden zouden zijn.

De tongetjes waren de enige vissen die in de mesocosms werden ingezet, omdat verwacht werd dat de PS-korrels snel naar de bodem zouden zinken waar ze vooral een risico zouden vormen voor vissen die op daar hun voedsel zoeken, zoals tong. Tegen de verwachtingen in bleef echter gedurende de gehele proef een deel van de PS-korrels in de waterkolom zweven. Deze zwevende korrels kunnen als voedsel (bijv. viseieren) worden gezien door pelagische vissen. Gegevens ontbreken, maar wellicht 
zijn pelagische plankton-etende vissen minder goed in staat om plastics te verwerken dan bodemvissen, waarvan het spijsverteringssysteem erop is ingericht om onverteerbare delen als schelpresten en zand te verwerken. Het is daarom mogelijk dat er eerder problemen zullen ontstaan bij plankton-etende pelagische vis, dan bij platvis. Het risico betreft vooral kleine vis wanneer de grootte van de PS-korrels kritisch is in relatie tot de darmdiameter. Dit soort kleine vis komt in grote getalen in de Waddenzee voor (bijv. jonge haring en sprot, of stekelbaars). Mogelijk is dus het risico voor deze vissen in dit rapport onderschat. Onderzoek naar dit aspect zou bij voorkeur in mesocosms moeten worden uitgevoerd, waar de vissen natuurlijk gedrag vertonen en kunnen beschikken over een continu en gevarieerd planktonaanbod zoals dat ook in het veld aanwezig is.

\subsection{Eindconclusie}

In de laagste testconcentratie werden in de mesocosms geen significante effecten gevonden. Dit kwam overeen met 326 PS-korrels per $\mathrm{m}^{2}$, en het scenario dat alle door MSC Zoe verloren PS-korrels zich homogeen verspreid hebben over $10 \%$ (ca. 15.000 ha) van het oppervlak van de Nederlandse Waddenzee. Hogere onderzochte concentraties, vanaf 3260 korrels per $\mathrm{m}^{2}$, veroorzaakten wel significante effecten op zeepokken, bodemfauna en juveniele platvis (tong). Tot en met de hoogst geteste concentratie van meer dan 300.000 korrels per $\mathrm{m}^{2}$ bleef de omvang van de negatieve effecten beperkt. Bij de beschouwing van deze resultaten moet wel worden opgemerkt dat pelagische plankton-etende jonge vis in deze studie niet aanwezig was en dat het risico voor deze vissen mogelijk is onderschat. 


\section{Kwaliteitsborging}

Wageningen Marine Research beschikt over een ISO 9001:2015 gecertificeerd kwaliteitsmanagementsysteem. Dit certificaat is geldig tot 15 december 2021. De organisatie is gecertificeerd sinds 27 februari 2001. De certificering is uitgevoerd door DNV GL. 


\section{Literatuur}

Besseling, E., Wegner, A., Foekema, E.M., van den Heuvel-Greve, M.J., Koelmans, A.A., 2013. Effects of Microplastic on Fitness and PCB Bioaccumulation by the Lugworm Arenicola marina (L.). Environmental Science \& Technology 47, 593-600.

Redondo-Hasselerharm, P.E., Gort, G., Peeters, E.T.H.M., Koelmans, A.A., 2020. Nano- and microplastics affect the composition of freshwater benthic communities in the long term. Sci. Adv. 6 (5), eaay4054 (2020). 


\section{Verantwoording}

Rapport C019/21

Projectnummer: 4315100134

Dit rapport is met grote zorgvuldigheid tot stand gekomen. De wetenschappelijke kwaliteit is intern getoetst door een collega-onderzoeker en het verantwoordelijk lid van het managementteam van Wageningen Marine Research

Akkoord:

Afra Asjes, MSc

Onderzoeker

Handtekening:

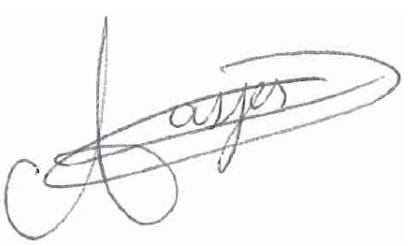

Datum:

10 maart 2021

Akkoord:

Drs. J. Asjes

Manager Integratie

Handtekening:

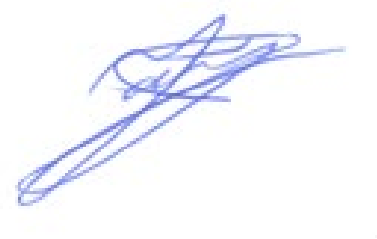

Datum:

10 maart 2021 
Wageningen Marine Research

T: $+31(0) 317480900$

E: marine-research@wur.nl

www.wur.nl/marine-research

Bezoekers adres:

- Ankerpark 271781 AG Den Helder

- Korringaweg 7, 4401 NT Yerseke

- Haringkade 1, 1976 CP IJmuiden
Wageningen Marine Research levert met kennis, onafhankelijk wetenschappelijk onderzoek en advies een wezenlijke bijdrage aan een duurzamer, zorgvuldiger beheer, gebruik en bescherming van de natuurlijke rijkdommen in zee-, kust- en zoetwatergebieden.
Wageningen Marine Research is onderdeel van Wageningen University \& Research. Wageningen University \& Research is het samenwerkingsverband tussen Wageningen University en Stichting Wageningen Research en heeft als missie: 'To explore the potential of nature to improve the quality of life' 